\title{
Template-Directed Photochemical Homodimerization and Heterodimerization Reactions of Cinnamic Acids
}

\author{
Bilge Banu Yagci, Yunus Zorlu, and Yunus Emre Türkmen*
}

Cite This: J. Org. Chem. 2021, 86, 13118-13128

Read Online

ABSTRACT: We developed a general method for the selective photochemical homo- and heterodimerization of cinnamic acid derivatives with the use of commercially available 1,8-dihydroxynaphthalene as a covalent template. A variety of symmetrical and unsymmetrical $\beta$-truxinic acids were obtained in high yields and as single diastereomers. The use of a template not only provides the alignment of the two olefins with suitable proximity $(<4.2 \AA)$ but also

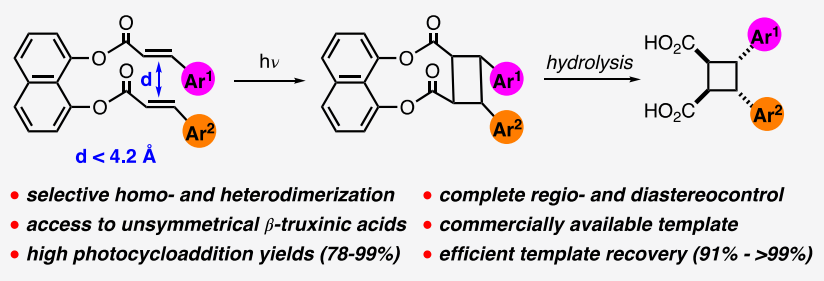
allows the heterodimerization of two different cinnamic acids, leading to unsymmetrical $\beta$-truxinic acid products.

$\mathrm{P}$ hotochemical $[2+2]$ cycloaddition reactions constitute one of the most direct and effective methods for the construction of four-membered rings. ${ }^{1}$ One particular type of $[2+2]$ cycloadditions that attracted significant attention is the photodimerization of cinnamic acid derivatives due to the challenges associated with this transformation in terms of regio- and stereoselectivity as well as reactivity. ${ }^{2}$ In addition, [2 +2 ] cycloadducts of cinnamic acids are attractive synthetic targets because of their diverse and promising biological activity profiles and their presence in various natural products. ${ }^{3}$ Irradiation of cinnamic acid derivatives in solution leads predominantly to $E / Z$ photoisomerization, and therefore, efforts to achieve these transformations were focused primarily on solid-state photochemistry. ${ }^{4}$ Early studies led to the topochemical reaction principles described by Schmidt for photochemical $[2+2]$ cycloadditions in solid state. ${ }^{4 c, 5}$ According to these criteria, for such a photochemical reaction to take place, alkenes must be aligned parallel to each other with a distance of 3.5-4.2 $\AA$ between the reactive olefin centers. The crystal structures of certain olefins fulfill these criteria so that irradiation of such compounds in solid state directly affords the corresponding cycloaddition products. For instance, irradiation of the $\alpha$-polymorph of trans-cinnamic acid (1) with UV light gives selectively the head-to-tail homodimerization product $\alpha$-truxillic acid (2), whereas the photocycloaddition of the metastable $\beta$-polymorph leads to the formation of the head-to-head dimer $\beta$-truxinic acid (3a) (Scheme 1). ${ }^{5 \mathrm{~b}, 6}$ On the other hand, the $\gamma$-polymorph does not undergo a $[2+2]$ cycloaddition upon irradiation since the distance between the olefin centers is greater than $4.2 \AA{ }^{4 a, 5 c}$

The geometrical requirements described by the Schmidt criteria for alkenes to undergo photochemical cycloadditions make such reactions highly difficult to predict, design, and control, which eventually limit the broad applicability of this methodology. In order to circumvent this problem, the use of
Scheme 1. Photodimerization Reactions of Cinnamic Acid

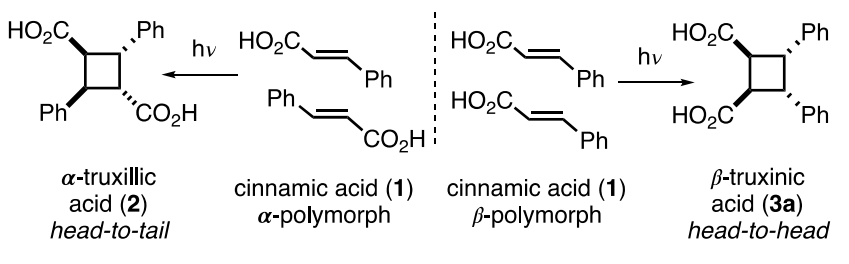

covalent and noncovalent templates was developed so that the relative positioning of alkenes could be controlled with the help of such templates. ${ }^{7}$ Interactions such as hydrogen bonding, halogen bonding, and metal coordination have been elegantly utilized in the design of many noncovalent templates for photochemical $[2+2]$ reactions in solid state. ${ }^{8-10}$ Whereas the use of noncovalent interactions obviates the covalent linking of the substrates to the template and the removal of the product from it, the requirement of cocrystallization of substrates with the template limits the scope of this strategy.

Surprisingly, covalent template-directed photochemical $[2+$ 2] cycloadditions are much less common. ${ }^{11-15}$ After the successful demonstration by Hopf, Jones, and Desvergne that the topochemical principles could be applied to solution chemistry, ${ }^{16}$ König and co-workers investigated three diols as covalent templates in the photochemical homodimerization of unsubstituted trans-cinnamic acid (1) in solution (Scheme $2 a){ }^{12}$ In 2002, Hopf and co-workers reported the use of 4,15-

Received: June 29, 2021

Published: September 1, 2021 
Scheme 2. Previous Examples of Covalent TemplateDirected Photochemical $[2+2]$ Cycloadditions

(a) König, 1996 (ref 12)<smiles>O=C(/C=C/c1ccccc1)OCc1ccccc1COC(=O)/C=C/c1ccccc1</smiles><smiles>O=C(OCc1ccccc1COC(=O)[C@@H]1C(c2ccccc2)C(c2ccccc2)[C@@H]1c1ccccc1)c1ccccc1</smiles>

- only homodimerization of cinnamic acid (1) reported

(b) Hopf, 2002 (ref 13)
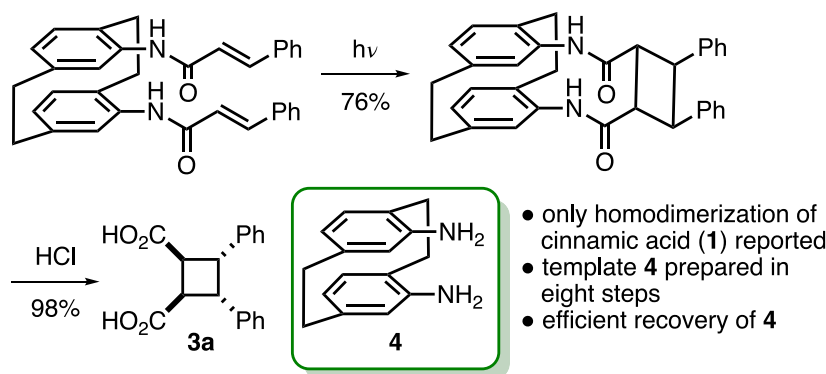

(c) Wolf, 2010 (ref 15)

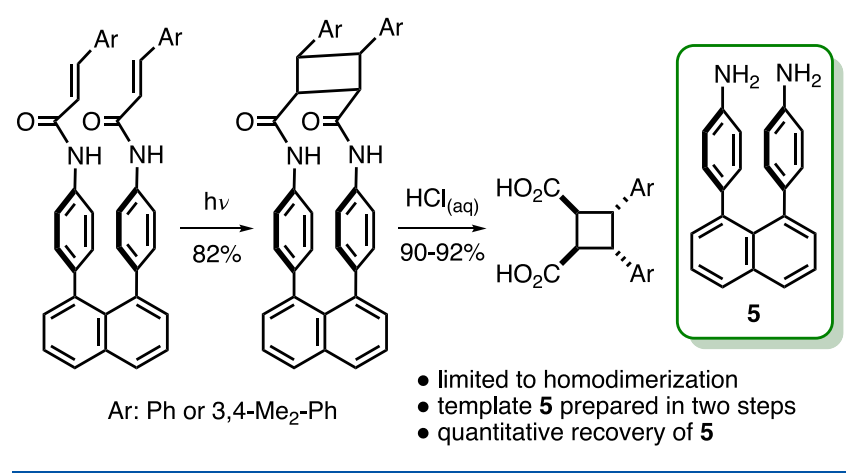

diamino[2.2] paracyclophane (4) as an effective covalent template for the homodimerization of cinnamic acid (1) in solution (Scheme $2 \mathrm{~b}$ ). ${ }^{13}$ Whereas template 4 was shown to be reusable, its eight-step preparation decreases the synthetic utility of this approach. In another study reported by Wolf and co-workers in 2010, template $\mathbf{5}$ was utilized in the photochemical homodimerization of two cinnamic acid derivatives (Scheme 2c). ${ }^{15}$

The $[2+2]$ cycloadditions of cinnamic acid derivatives mentioned so far are predominantly homodimerizations, in which reactions of two identical olefins afford symmetrical cyclobutanes. Indeed, a very high degree of homoselectivity was observed by Nguyen and co-workers even when a suspension of several cinnamic acids in cyclohexane was irradiated. ${ }^{17}$ Moreover, visible-light photocatalytic $[2+2]$ cycloadditions of cinnamic acid derivatives were shown to furnish symmetrical $\delta$-truxinic acid-based products arising from the anti-head-to-head homodimerization process. ${ }^{18,19}$ On the other hand, photochemical heterodimerization reactions, where two different cinnamic acids react selectively to give unsymmetrical cyclobutanes, are very rare. The few known examples of such heterodimerizations require either solid solutions or cocrystals of two cinnamic acid derivatives. ${ }^{20,21}$ The requirement of two different cinnamic acids to form a cocrystal or solid solution imposes a serious limitation on the scope of this type of heterodimerization reaction. In this context, a general method for the selective and controlled photochemical heterodimerization of cinnamic acids remains elusive. Against this background, we now report a simple and general solution to this long-standing problem.

During our recent studies on the use of 1,8-dihydroxynaphthalene $(1,8-\mathrm{DHN}, 6)$ as a hydrogen bonding catalyst, we observed that the two $-\mathrm{OH}$ groups of $1,8-\mathrm{DHN}$ could be methylated in a sequential and selective manner due to the intramolecular $\mathrm{HB}$ present in its structure. ${ }^{22}$ The proximity of the two oxygens, ${ }^{23}$ parallel orientation of the two $\mathrm{C}-\mathrm{O}$ bonds, the ability to selectively functionalize the two $-\mathrm{OHs}$, and its commercial availability led us to the hypothesis that $1,8-\mathrm{DHN}$ (6) would be an ideal covalent template for the photochemical $[2+2]$ homo- and heterodimerization reactions of cinnamic acids (Scheme 3). Moreover, covalent attachment of the

Scheme 3. Our Strategy for Selective Heterodimerization of Cinnamic Acids
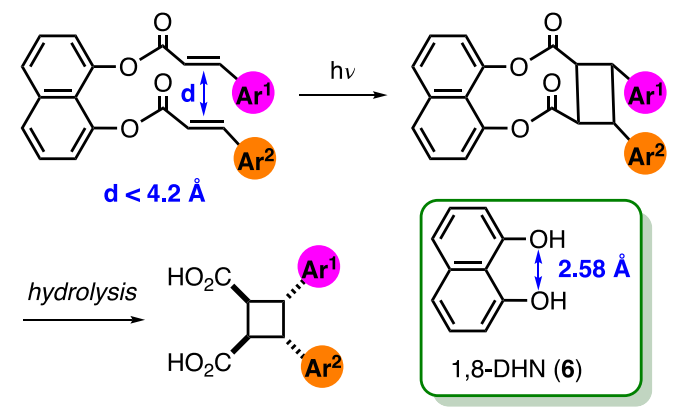

access to symmetrical and unsymmetrical $\beta$-truxinic acids

substrates to the template and detachment of the product were expected to be facile based on well-established esterification and saponification reactions under mild conditions.

In order to test our hypothesis, we first checked the feasibility of using 1,8-DHN (6) as a template in the photodimerization of trans-cinnamic acid (1) (Table 1). Covalent attachment of two cinnamic acid units to the

Table 1. Template-Directed Photochemical syn-Head-toHead Homodimerization of trans-Cinnamic Acid (1)

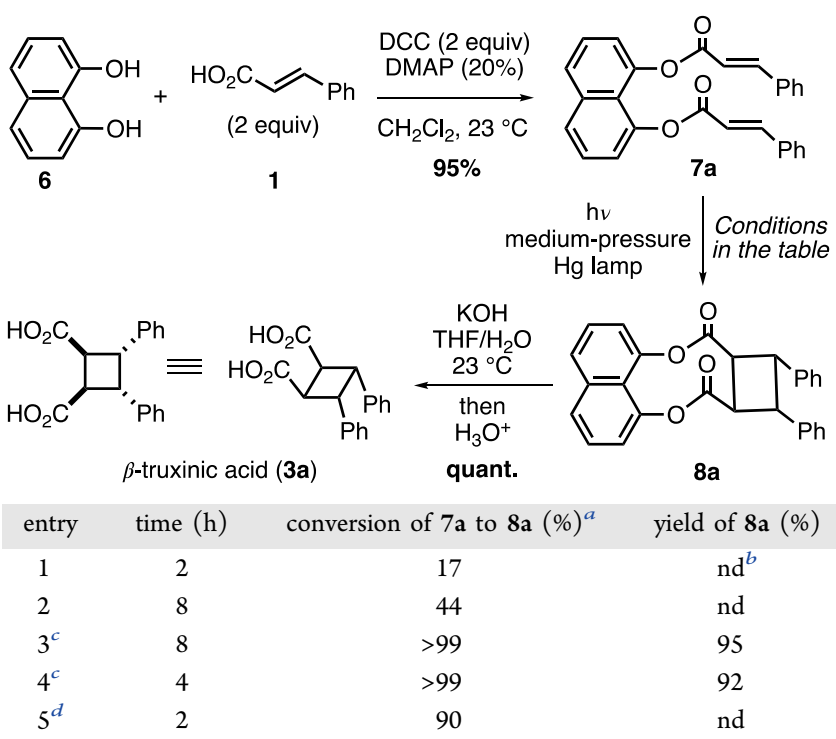

${ }^{a}$ Determined by ${ }^{1} \mathrm{H}$ NMR spectroscopy. ${ }^{b}$ nd $=$ not determined. ${ }^{c}$ The solid reaction mixture was mixed every $2 \mathrm{~h} .{ }^{d}$ The solid reaction mixture was mixed after $1 \mathrm{~h}$. 
template was achieved by double esterification of 6 in the presence of DCC and DMAP, resulting in the isolation of diester $7 \mathbf{a}$ in a $95 \%$ yield. Irradiation of $7 \mathbf{a}$ in solid state was examined with the use of a $400 \mathrm{~W}$ medium-pressure $\mathrm{Hg}$ lamp. When $7 \mathrm{a}$ was irradiated continuously for 2 and $8 \mathrm{~h}$, the $[2+2]$ cycloaddition product $8 \mathrm{a}$ was observed to form with $17 \%$ and $44 \%$ conversion, respectively, as determined by ${ }^{1} \mathrm{H}$ NMR spectroscopy (entries 1 and 2). Mixing the solid mixture at certain intervals was found to have a substantial positive effect on the progress of the reaction. We were pleased to obtain diester $\mathbf{8 a}$ with quantitative conversion and an almost quantitative yield when the sample was irradiated for 8 or 4 $\mathrm{h}$ in total with mixing the solid reaction mixture every $2 \mathrm{~h}$ (entries 3 and 4). However, irradiation of $7 \mathrm{a}$ for $2 \mathrm{~h}$ with a mixing of the sample after $1 \mathrm{~h}$ resulted in $90 \%$ conversion (entry 5). It should be noted that all these photochemical reactions are very clean transformations with no side products and no decomposition of $7 \mathbf{a}$ or $\mathbf{8 a}$. In order to check the possibility of utilizing a different irradiation source, we tested the photoreaction of $7 \mathbf{a}$ to $\mathbf{8 a}$ using a commercial gel nail dryer equipped with four $9 \mathrm{~W}$ UVA fluorescent bulbs $(365 \mathrm{~nm}){ }^{24}$ Pleasingly, 7a was observed to form cycloadduct 8a with $95 \%$ conversion and $92 \%$ isolated product yield upon $8 \mathrm{~h}$ of irradiation. $^{25}$ This preliminary result shows that our strategy can be successfully applied with other irradiation sources. Finally, hydrolysis of diester $\mathbf{8 a}$ was accomplished under basic conditions to afford $\beta$-truxinic acid (3a) as a single diastereomer in a quantitative yield along with complete recovery of template 6 . Control experiments, in which 7a was heated at $90{ }^{\circ} \mathrm{C}$ under dark either as a solid or as a solution in toluene for $6 \mathrm{~h}$, indicated the absence of any reaction under thermal conditions. ${ }^{26}$

The results obtained with the photodimerization of $7 \mathrm{a}$ demonstrated that $1,8-\mathrm{DHN}$ (6) could indeed act as a suitable template for such $[2+2]$ reactions. We then sought to gain information on the geometries of the substrate-template conjugate before and after the cycloaddition. To this end, the structures of $7 \mathbf{a}$ and $8 \mathbf{a}$ were determined by single-crystal $\mathrm{X}$-ray crystallography (Figure 1). The X-ray structure of $7 \mathbf{a}$
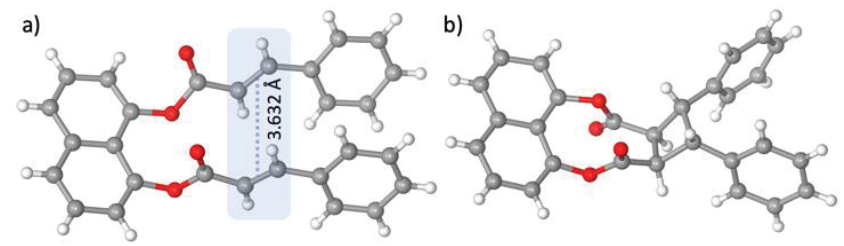

Figure 1. X-ray crystal structures of (a) diester $7 \mathbf{a}$ and (b) $[2+2]$ cycloaddition product $\mathbf{8 a}$.

revealed the ideal parallel alignment of the two cinnamic acid units with a distance of $3.632 \AA$ between the olefin centers, which is in perfect agreement with the Schmidt criteria (Figure 1a). ${ }^{4 c}$ Moreover, the crystal structure of 8 a confirmed its relative stereochemistry and the stereocontrolled nature of the photoreaction as syn-head-to-head dimerization (Figure 1b). The perfect agreement of the NMR data of the hydrolysis product 3a with those of $\beta$-truxinic acid reported in the literature ${ }^{6}$ provided further confirmation of our structural assignment.

Encouraged by these results, we next sought to investigate homo- and heterodimerization reactions of other cinnamic acid derivatives (Table 2). Irradiation of $7 \mathbf{b}$ bearing 4-methoxyphenyl substituents for $12 \mathrm{~h}$ afforded cycloadduct $\mathbf{8 b}$ in $78 \%$

Table 2. Template-Directed Photochemical Homo- and Heterodimerization of $\boldsymbol{\alpha}, \boldsymbol{\beta}$-Unsaturated Carboxylic Acids

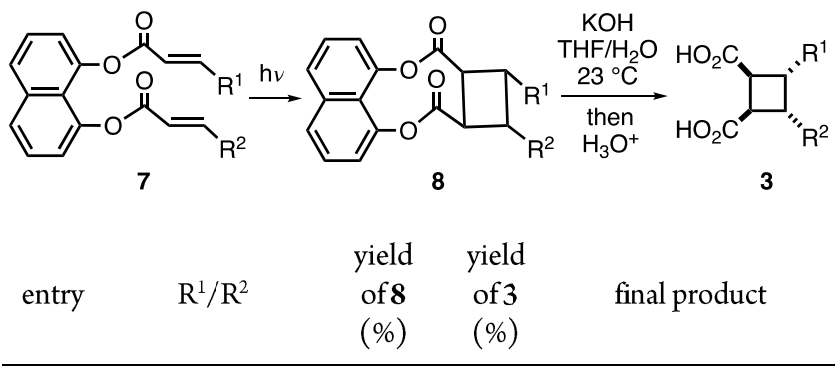

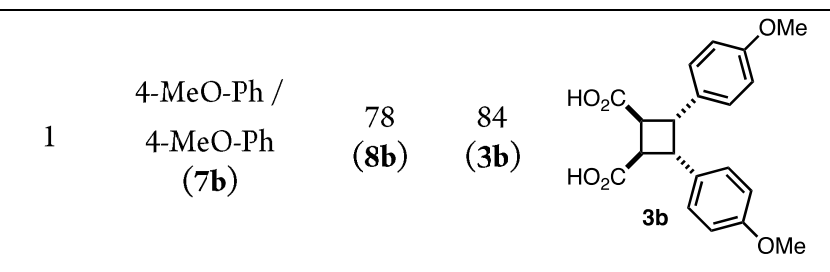

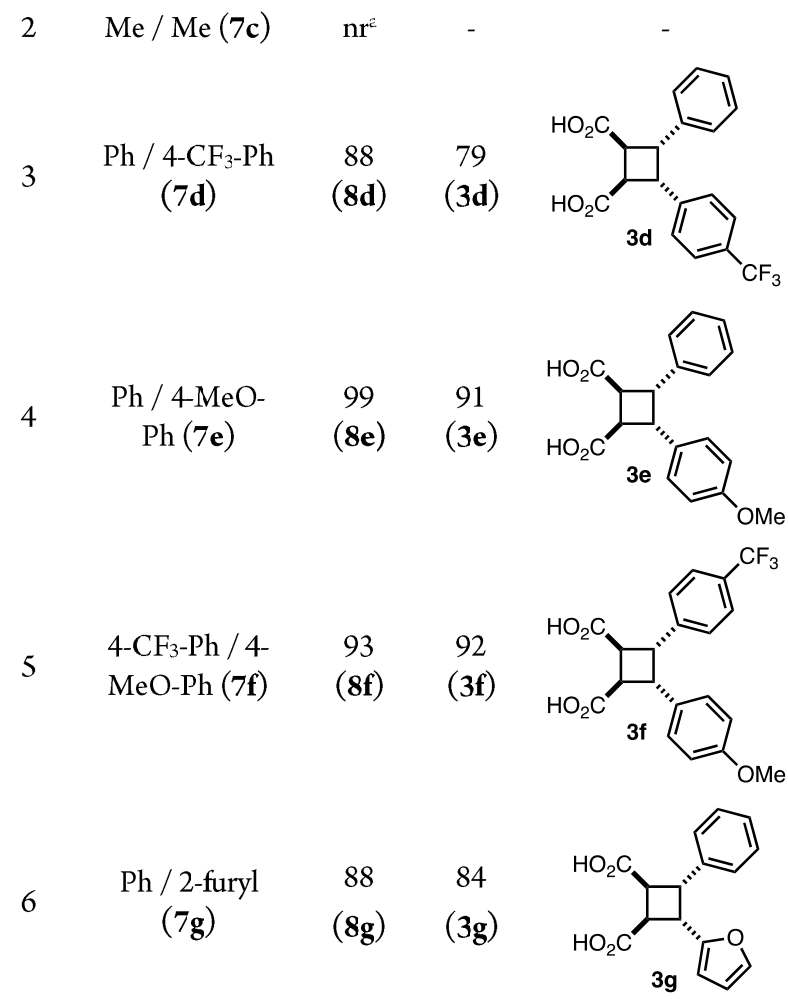

$a_{\mathrm{nr}}=$ no reaction.

yield, which was subsequently hydrolyzed to the $\beta$-truxinic acid derivative $\mathbf{3 b}$ in high yield ( $84 \%$, entry 1 ). The effect of having an aliphatic group at the $\beta$-position of the acrylate moiety was examined through the use of diester $7 \mathbf{c}$, which was prepared via the double esterification of $1,8-\mathrm{DHN}$ (6) with crotonic acid. Unfortunately, irradiation of $7 \mathrm{c}$ did not provide any cycloadduct, and the reactant was observed to remain intact (entry 2). Next, we turned our attention to the photochemical heterodimerizations of unsymmetrical substrates. For this purpose, diester $\mathbf{7 d}$ that bears phenyl and 4-trifluoromethylphenyl substituents was synthesized selectively and in high yield via sequential esterification reactions (see the Exper- 
imental Section). To our delight, irradiation of $7 \mathbf{d}$ for $6.5 \mathrm{~h}$ afforded the $[2+2]$ heterodimerization product $8 \mathrm{~d}$ in $88 \%$ yield (entry 3 ). Its hydrolysis gave the unsymmetrical cyclobutanedicarboxylic acid $\mathbf{3 d}$ as a single diastereomer (79\% yield). Another unsymmetrical substrate tested was diester 7e with phenyl and 4-methoxyphenyl substituents. Gratifyingly, 7e underwent the photochemical [2+2] reaction successfully with $8 \mathrm{~h}$ of irradiation and gave cycloadduct $8 \mathbf{e}$ in 99\% yield (entry 4). Diastereomerically pure, unsymmetrical dicarboxylic acid product 3e was isolated in $91 \%$ yield upon hydrolysis of 8e. We next investigated the reactivity of diester $7 \mathbf{f}$, which possesses electron-donating 4-OMe and electronwithdrawing $4-\mathrm{CF}_{3}$ groups on each of its phenyl rings. This compound was also observed to be a competent substrate with the newly developed methodology, and cyclobutane $8 \mathrm{f}$ was obtained in 93\% yield upon irradiation for $8 \mathrm{~h}$ (entry 5). Its subsequent hydrolysis gave dicarboxylic acid 3f in $92 \%$ yield. Finally, we opted to investigate the heterodimerization of a substrate containing a heteroaromatic cinnamic acid derivative. In order to achieve this goal, diester $7 \mathbf{g}$ with phenyl and 2 -furyl substituents was synthesized by sequential esterification. Irradiation of $7 \mathrm{~g}$ for $8 \mathrm{~h}$ furnished the cyclobutane product $8 \mathrm{~g}$ in $88 \%$ yield as a single diastereomer (entry 6). Hydrolysis of $\mathbf{8 g}$ afforded furan-containing cyclobutanedicarboxylic acid $\mathbf{3 g}$ in high yield (84\%). This result indicates that the newly developed methodology can be extended to reactions of acrylic acids with heteroaromatic substituents at the $\beta$-position.

The crystal structure of the unsymmetrical diester $7 \mathbf{f}$ was elucidated by single crystal XRD analysis (Figure 2). Whereas

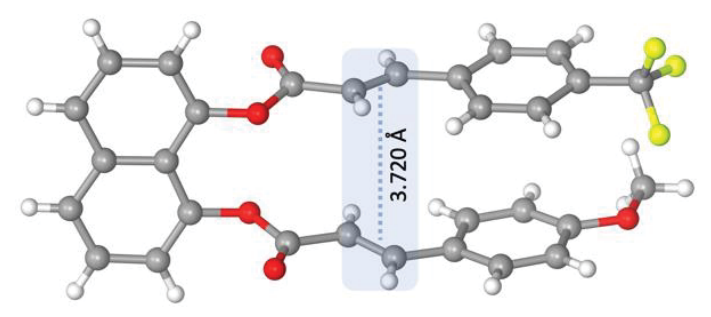

Figure 2. X-ray crystal structure of diester $7 \mathbf{f}$.

the distance between the olefin centers was found to be $3.72 \AA$, the two carbonyls of $\mathbf{7 f}$, in contrast to $7 \mathbf{a}$, were observed to have opposite orientations resulting in a criss-crossed geometry for the reacting olefins. ${ }^{26} \mathrm{~A}[2+2]$ cycloaddition with this type of arrangement of olefins is not only expected to be unfavorable geometrically ${ }^{27}$ but also would give a $\delta$-truxinic acid via an anti-head-to-head dimerization. However, extensive NMR spectroscopic studies on the structure of cyclobutane $3 f$ including NOESY and $J$ coupling constant analysis confirmed its $\beta$-truxinic acid nature, which points to a syn-head-to-head dimerization of $7 \mathbf{f}^{26}$ This sort of syn-head-to-head photodimerization was observed by others, ${ }^{8 \mathrm{k}, 28}$ and it was proposed to be caused by the pedal motion of olefins prior to photocycloaddition so that the two olefins adopt a parallel alignment suitable for the cycloaddition. ${ }^{27,29}$ In our case, we propose that a similar pedal motion might be responsible for the high efficiency of the $[2+2]$ photocycloaddition of $7 \mathbf{f}$.

Having shown the successful application of the newly developed methodology to a variety of photochemical homoand heterodimerization reactions, we next examined its scalability. To this end, a suspension of $7 \mathrm{a}(1.2 \mathrm{mmol})$ in $n$ heptane was irradiated for $16 \mathrm{~h}$, and cycloadduct $8 \mathrm{a}$ was isolated in $72 \%$ yield as a single diastereomer (Scheme 4). Importantly, unreacted 7 a could be reisolated efficiently (27\%)

Scheme 4. Scalability of the Photodimerization Reactions

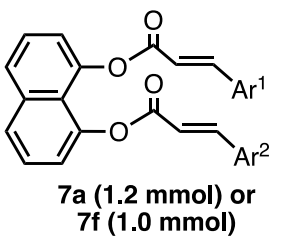

7f (1.0 mmol)

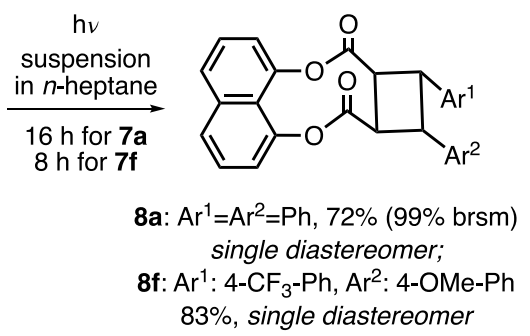

$83 \%$, single diastereomer at the end of the reaction, which makes the overall reaction yield $99 \%$ based on recovered starting material (brsm). A similar experiment was performed with the unsymmetrical diester $7 \mathbf{f}$. The irradiation of a suspension of $7 \mathbf{f}(1.0 \mathrm{mmol})$ in $n$-heptane for $8 \mathrm{~h}$ afforded diastereomerically pure $[2+2]$ heterodimerization product $\mathbf{8 f}$ in $83 \%$ yield (Scheme 4 ). These results clearly demonstrate the suitability of the present method for scale up.

In summary, we present a general solution for the selective photochemical homo- and heterodimerization of cinnamic acids. The commercially available $1,8-\mathrm{DHN}$ (6) is used as a template to enable the preorganization of the two cinnamic acid units for an efficient photocycloaddition. The ability to attach sequentially two different cinnamic acids to the template paved the way for a highly selective photochemical heterodimerization. The photochemical $[2+2]$ reaction proceeds in high yields (78-99\%) and with complete regioand diastereocontrol, affording a variety of symmetrical and unsymmetrical $\beta$-truxinic acids. The template was found to be recoverable in high yields during the detachment step of the $\beta$ truxinic acid products from the template. Importantly, the cycloaddition step was found to be scalable when the photochemical reactions were carried out in heptane as suspension. Our current efforts are focused on the extent of the utility of this strategy to the synthesis of other unsymmetrical cyclobutane scaffolds.

\section{EXPERIMENTAL SECTION}

General Information. All solution-phase reactions were performed using oven-dried glassware under an inert atmosphere of nitrogen. Reactions were monitored by thin-layer chromatography (TLC) using aluminum-backed plates precoated with silica gel (Silicycle, Silica Gel $60 \mathrm{~F}_{254}$ ). UV light and/or $\mathrm{KMnO}_{4}$ staining solution were used for TLC visualization. Flash column chromatography was performed on Silicycle 40-63 $\mu \mathrm{m}$ (230-400 mesh) flash silica gel. ${ }^{1} \mathrm{H}$ NMR $(400 \mathrm{MHz}),{ }^{13} \mathrm{C}\left\{{ }^{1} \mathrm{H}\right\}$ NMR $(100 \mathrm{MHz})$, and ${ }^{19} \mathrm{~F}\left\{{ }^{1} \mathrm{H}\right\}$ NMR (376 MHz) spectra were recorded using a Bruker Avance 400 spectrometer in $\mathrm{CDCl}_{3}$ and DMSO- $d_{6}$. Internal standard signal (TMS, $0 \mathrm{ppm}$ ) or residual solvent signals (chloroform at 7.26 $\mathrm{ppm}$, and DMSO at $2.50 \mathrm{ppm}$ for ${ }^{1} \mathrm{H}$ NMR; chloroform at $77.16 \mathrm{ppm}$ and DMSO at $39.52 \mathrm{ppm}$ for ${ }^{13} \mathrm{C}\left\{{ }^{1} \mathrm{H}\right\}$ NMR spectra) were used for the calibration of ${ }^{1} \mathrm{H}$ and ${ }^{13} \mathrm{C}\left\{{ }^{1} \mathrm{H}\right\}$ NMR spectra. Trifluoroacetic acid $\left(\mathrm{CF}_{3} \mathrm{CO}_{2} \mathrm{H}\right)$ was used as an external reference $(-76.55 \mathrm{ppm})$ for ${ }^{19} \mathrm{~F}\left\{{ }^{1} \mathrm{H}\right\}$ NMR experiments. ${ }^{1} \mathrm{H}$ NMR data are reported as follows: chemical shift (parts per million, ppm), integration, multiplicity $(\mathrm{s}=$ singlet, $\mathrm{d}=$ doublet, $\mathrm{t}=$ triplet, $\mathrm{dd}=$ doublet of doublets, $\mathrm{m}=$ multiplet, br = broad, app = apparent), coupling constant $(\mathrm{Hz})$. Infrared (FTIR) spectra were recorded on a Bruker Alpha-PlatinumATR spectrometer with only selected peaks reported. High-resolution mass spectral analyses (HRMS) were performed on Agilent Technologies 6530 QTOF-LC/MS at DAYTAM-East Anatolia 
High Technology Application and Research Center, Atatürk University, and on Agilent Technologies $6224 \mathrm{TOF}$ LC/MS at UNAM-National Nanotechnology Research Center and Institute of Materials Science and Nanotechnology, Bilkent University. Singlecrystal X-ray diffraction analysis was performed at Gebze Technical University, Turkey. Photochemical reactions were performed using a reactor obtained from Photochemical Reactors Ltd., composed of a $400 \mathrm{~W}$ medium-pressure mercury lamp (3040/PX0686) and a quartz double-walled immersion well with water cooling. Regular microscope slides made of soda-lime glass were used without any additional filters for the photochemical reactions in solid state. The slides were kept at ca. $4 \mathrm{~cm}$ away from the lamp during the irradiation. All photochemical reactions were performed inside a fully closed safety cabinet. 1,8Dihydroxynaphthalene (1,8-DHN) was purchased from abcr Co. and used as received. Anhydrous $\mathrm{CH}_{2} \mathrm{Cl}_{2}$ was purchased from Acros Organics (AcroSeal). All other commercially available reagents were used as received unless stated otherwise.

Naphthalene-1,8-diyl(2E,2'E)-bis(3-phenyl acrylate) (7a). 1,8 -DHN (6) $(100 \mathrm{mg}, 0.62 \mathrm{mmol})$ was dissolved in $15 \mathrm{~mL}$ of anhydrous $\mathrm{CH}_{2} \mathrm{Cl}_{2}$ in a $100 \mathrm{~mL}$, round-bottomed flask at $23^{\circ} \mathrm{C}$ under nitrogen. trans-Cinnamic acid (1) (185 mg, $1.25 \mathrm{mmol})$, DCC (258 $\mathrm{mg}, 1.25 \mathrm{mmol})$, and DMAP $(15.3 \mathrm{mg}, 0.125 \mathrm{mmol})$ were added sequentially. The resulting cloudy, heterogeneous mixture was stirred at $23{ }^{\circ} \mathrm{C}$ for $24 \mathrm{~h}$. TLC analysis indicated full consumption of 1,8 DHN (6). The reaction mixture was quenched with a $10 \%(\mathrm{w} / \mathrm{v})$ aqueous solution of citric acid $(30 \mathrm{~mL})$ and $\mathrm{H}_{2} \mathrm{O}(10 \mathrm{~mL})$. The two phases were partitioned. The organic phase was washed once with brine. It was then dried over anhydrous $\mathrm{Na}_{2} \mathrm{SO}_{4}$, filtered, and concentrated under a vacuum. Purification by column chromatography $\left(\mathrm{SiO}_{2} ; \mathrm{CH}_{2} \mathrm{Cl}_{2} /\right.$ hexanes $\left.=1: 1\right)$ afforded pure $7 \mathbf{a}(248 \mathrm{mg}, 95 \%)$ as a pale yellow solid.

Synthesis of Diester 7a on a $6.2 \mathrm{mmol}$ Scale. 1,8-DHN (6) (1.00 g, $6.24 \mathrm{mmol}$ ) was dissolved in $20 \mathrm{~mL}$ of anhydrous $\mathrm{CH}_{2} \mathrm{Cl}_{2}$ in a 100 $\mathrm{mL}$, round-bottomed flask at $23{ }^{\circ} \mathrm{C}$ under nitrogen. trans-Cinnamic acid (1) $(1.85 \mathrm{~g}, 12.5 \mathrm{mmol})$, DCC $(2.58 \mathrm{~g}, 12.5 \mathrm{mmol})$, and DMAP $(153 \mathrm{mg}, 1.25 \mathrm{mmol}$ ) were added sequentially. The resulting cloudy, heterogeneous mixture was stirred at $23{ }^{\circ} \mathrm{C}$ for $40 \mathrm{~h}$. The reaction mixture was quenched with a $10 \%(\mathrm{w} / \mathrm{v})$ aqueous solution of citric acid and $\mathrm{H}_{2} \mathrm{O}$. The two phases were partitioned. The organic phase was washed once with brine. It was then dried over anhydrous $\mathrm{Na}_{2} \mathrm{SO}_{4}$, filtered, and concentrated under a vacuum. Purification by column chromatography $\left(\mathrm{SiO}_{2} ; \mathrm{CH}_{2} \mathrm{Cl}_{2} /\right.$ hexanes = 1:1) afforded pure $7 \mathrm{a}(2.29 \mathrm{~g}, 87 \%)$ as a pale yellow solid. Mp: $222-223^{\circ} \mathrm{C}\left(\mathrm{CHCl}_{3}\right) \cdot R_{f}$ $=0.56\left(\mathrm{CH}_{2} \mathrm{Cl}_{2} /\right.$ hexanes $\left.=1: 1\right) .{ }^{1} \mathrm{H}$ NMR $\left(400 \mathrm{MHz} ; \mathrm{CDCl}_{3}\right): \delta$ $7.86(2 \mathrm{H}, \mathrm{d}, J=16.0 \mathrm{~Hz}), 7.82(2 \mathrm{H}, \mathrm{d}, J=8.3 \mathrm{~Hz}), 7.50(2 \mathrm{H}, \mathrm{t}, J=$ $7.9 \mathrm{~Hz}), 7.31-7.25(6 \mathrm{H}, \mathrm{m}), 7.21(2 \mathrm{H}, \mathrm{d}, J=7.3 \mathrm{~Hz}), 7.13(4 \mathrm{H}, \mathrm{t}, J=$ $7.6 \mathrm{~Hz}), 6.63(2 \mathrm{H}, \mathrm{d}, J=16.0 \mathrm{~Hz}) .{ }^{13} \mathrm{C}\left\{{ }^{1} \mathrm{H}\right\}$ NMR $(100 \mathrm{MHz}$; $\left.\mathrm{CDCl}_{3}\right): \delta 166.0,147.1,145.3,136.9,133.9,130.7,128.9,128.3$, 127.0, 126.2, 121.5, 120.7, 117.4. FTIR: $\nu_{\max }\left(\right.$ ATR, film) $/ \mathrm{cm}^{-1} 3061$, 2924, 2853, 1718, 1633, 1601, 1576, 1497, 1450. HRMS (ESI+): calcd for $\mathrm{C}_{28} \mathrm{H}_{20} \mathrm{O}_{4} \mathrm{Na}[\mathrm{M}+\mathrm{Na}]^{+}$, 443.1254; found, 443.1255.

9,10-Diphenyl-8a,9,10,10a-tetrahydrocyclobuta[g]naphtho[1,8-bc][1,5]dioxonine-8,11-dione (8a). Diester 7a (25.6 mg, $0.061 \mathrm{mmol}$ ) was placed between two glass microscope slides as a solid powder. The sample was irradiated in a safety box using a $400 \mathrm{~W}$ broadband medium-pressure $\mathrm{Hg}$ lamp for $4 \mathrm{~h}$ (Figure S1). The solid powder was mixed with a spatula to ensure homogeneity after two $\mathrm{h}$. At the end of $4 \mathrm{~h}$ in total, the sample was transferred to a vial by washing with $\mathrm{CDCl}_{3} .{ }^{1} \mathrm{H}$ NMR spectroscopic analysis indicated full conversion of diester $7 \mathbf{a}$ to the cyclobutane product $8 \mathbf{a}$. The presence of diester $7 \mathbf{a}$ or any other side product was not observed in this spectrum. Cyclobutane 8a was obtained as a light brown solid upon removal of the solvent $(23.3 \mathrm{mg}, 92 \%)$.

In another experiment, diester $7 \mathrm{a}(26.3 \mathrm{mg}, 0.063 \mathrm{mmol})$ was irradiated using the same experimental setup for $8 \mathrm{~h}$. The solid powder was mixed with a spatula to ensure homogeneity every $2 \mathrm{~h}$. At the end of $8 \mathrm{~h}$ in total, the sample was transferred to a vial by washing with $\mathrm{CDCl}_{3} .{ }^{1} \mathrm{H}$ NMR spectroscopic analysis indicated full conversion of diester $7 \mathbf{a}$ to the cyclobutane product $8 \mathbf{a}$. The presence of diester $7 \mathbf{a}$ or any other side product was not observed. Cyclobutane $\mathbf{8 a}$ was obtained as a light brown solid upon removal of the solvent $(24.9 \mathrm{mg}$, 95\%). Mp: $228-229^{\circ} \mathrm{C}\left(\mathrm{CHCl}_{3}\right) \cdot R_{f}=0.62\left(\mathrm{CH}_{2} \mathrm{Cl}_{2} /\right.$ hexanes $\left.=1: 1\right)$. ${ }^{1} \mathrm{H}$ NMR $\left(400 \mathrm{MHz} ; \mathrm{CDCl}_{3}\right): \delta 7.82(2 \mathrm{H}, \mathrm{d}, J=8.3 \mathrm{~Hz}), 7.51(2 \mathrm{H}, \mathrm{t}$, $J=7.9 \mathrm{~Hz}), 7.28(2 \mathrm{H}, \mathrm{d}, J=7.5 \mathrm{~Hz}), 7.17(4 \mathrm{H}, \mathrm{t}, J=7.3 \mathrm{~Hz}), 7.10$ $(2 \mathrm{H}, \mathrm{t}, J=7.2 \mathrm{~Hz}), 7.03(4 \mathrm{H}, \mathrm{d}, J=7.2 \mathrm{~Hz}), 4.77(2 \mathrm{H}$, app d, $J=6.0$ $\mathrm{Hz}), 4.24(2 \mathrm{H}$, app d, $J=6.0 \mathrm{~Hz}) .{ }^{13} \mathrm{C}\left\{{ }^{1} \mathrm{H}\right\}$ NMR $(100 \mathrm{MHz}$; $\left.\mathrm{CDCl}_{3}\right): \delta 170.1,145.5,138.2,137.1,128.3,127.9,127.1,126.8$, 126.5, 121.1, 119.6, 44.9, 44.3. FTIR: $\nu_{\max }$ (ATR, film) $/ \mathrm{cm}^{-1} 2924$, 2853, 1762, 1607, 1497, 1452, 1366. HRMS (ESI+): calcd for $\mathrm{C}_{28} \mathrm{H}_{21} \mathrm{O}_{4}[\mathrm{M}+\mathrm{H}]^{+}$, 421.1434; found, 421.1436.

Photochemical Reaction of $7 a$ using the UV Gel Nail Dryer. Diester 7a (20.3 mg, $0.048 \mathrm{mmol})$ was placed between two glass microscope slides as a solid powder. The sample was irradiated inside a UV gel nail dryer, equipped with four 9 W UVA fluorescent bulbs, for $8 \mathrm{~h}$ (Figure S3). The solid powder was mixed with a spatula to ensure homogeneity every hour. At the end of $8 \mathrm{~h}$ in total, ${ }^{1} \mathrm{H}$ NMR spectroscopic analysis indicated $95 \%$ conversion of diester $7 \mathbf{a}$ to the cyclobutane product 8a. Purification by column chromatography $\left(\mathrm{SiO}_{2} ; \mathrm{CH}_{2} \mathrm{Cl}_{2} /\right.$ hexanes $=1: 1$, then only $\left.\mathrm{CH}_{2} \mathrm{Cl}_{2}\right)$ afforded pure 8a $(18.7 \mathrm{mg}, 92 \%)$ as a white solid.

Photochemical Reaction of $7 a$ in Heptane on a $1.2 \mathrm{mmol}$ Scale. Heptane $(250 \mathrm{~mL})$ was degassed by purging with nitrogen and was transferred to an immersion well reactor flask containing solid diester $7 \mathbf{a}(505 \mathrm{mg}, 1.20 \mathrm{mmol})$. The resulting suspension was irradiated in a safety box using a $400 \mathrm{~W}$ broadband medium-pressure $\mathrm{Hg}$ lamp while stirring under a balloon of argon for $16 \mathrm{~h}$ (Figure S2). During the irradiation, the suspension was cooled continuously with a flow of cold water to prevent heating of the reaction mixture. The color turned from white to orange during the reaction. At the end of $16 \mathrm{~h}$, the sample was transferred to a round-bottomed flask by washing with $\mathrm{CH}_{2} \mathrm{Cl}_{2} .{ }^{1} \mathrm{H}$ NMR analysis of the crude mixture indicated $74 \%$ conversion to the cycloaddition product. Purification by column chromatography $\left(\mathrm{SiO}_{2} ; \mathrm{CH}_{2} \mathrm{Cl}_{2} /\right.$ hexanes $\left.=1: 1\right)$ afforded pure $\mathbf{8 a}$ $(361 \mathrm{mg}, 72 \%)$ as a pale yellow solid and pure starting material diester 7 a (138 $\mathrm{mg}, 27 \%$ recovery) as an orange solid.

(1R,2S,3R,4S)-3,4-Diphenylcyclobutane-1,2-dicarboxylic Acid (meso-3a). In a $20 \mathrm{~mL}$ scintillation vial, diester $8 \mathrm{a}(25 \mathrm{mg}$, $0.059 \mathrm{mmol}$ ) was dissolved in $2.0 \mathrm{~mL}$ of THF. Afterward, distilled water $(1.0 \mathrm{~mL})$ and $\mathrm{KOH}(65 \mathrm{mg}, 1.13 \mathrm{mmol})$ were added. The resulting mixture was stirred at $23{ }^{\circ} \mathrm{C}$ for $2 \mathrm{~h}$. It was then quenched with $1.0 \mathrm{M} \mathrm{HCl}$ solution until the $\mathrm{pH}$ was adjusted to $1-2$. The aqueous phase was extracted three times with EtOAc. The combined organic phase was then dried over anhydrous $\mathrm{Na}_{2} \mathrm{SO}_{4}$, filtered, and concentrated under a vacuum. Purification by column chromatography $\left(\mathrm{SiO}_{2} ; 0.5 \%(\mathrm{v} / \mathrm{v}) \mathrm{AcOH}\right.$ in EtOAc/hexanes = 1:1) afforded pure $3 \mathrm{a}(18 \mathrm{mg}, 100 \%)$ as a yellow solid and pure $1,8-\mathrm{DHN}(6)(10$ $\mathrm{mg}, 100 \%$ recovery) as a black solid.

In another experiment, diester 8a (200 $\mathrm{mg}, 0.48 \mathrm{mmol})$ was dissolved in $6.0 \mathrm{~mL}$ of THF in a $20 \mathrm{~mL}$ scintillation vial. Afterward, distilled water $(3.0 \mathrm{~mL})$ and $\mathrm{KOH}(507 \mathrm{mg}, 9.04 \mathrm{mmol})$ were added. The resulting mixture was stirred at $23{ }^{\circ} \mathrm{C}$ for $3 \mathrm{~h}$. It was then quenched with $1.0 \mathrm{M} \mathrm{HCl}$ solution until the $\mathrm{pH}$ was adjusted to $1-2$. The aqueous phase was extracted with EtOAc $(3 \times 30 \mathrm{~mL})$. The combined organic phase was then dried over anhydrous $\mathrm{Na}_{2} \mathrm{SO}_{4}$, filtered, and concentrated under a vacuum. Purification by column chromatography $\left(\mathrm{SiO}_{2}\right.$; first EtOAc/hexanes = 1:1, then 0.5\% (v/v) $\mathrm{AcOH}$ in EtOAc/hexanes = 1:1) afforded pure $3 \mathrm{a}(140 \mathrm{mg}, 98 \%)$ as a black solid, and pure $1,8-\mathrm{DHN}$ (6) (70 $\mathrm{mg}, 91 \%$ recovery) as a black solid. Mp: $206-208{ }^{\circ} \mathrm{C}$. (lit. $\left.{ }^{6} \mathrm{Mp}: 207.6-208.6{ }^{\circ} \mathrm{C}\right) . R_{f}=0.20(0.5 \%$ $(\mathrm{v} / \mathrm{v}) \mathrm{AcOH}$ in EtOAc/hexanes = 1:1 ${ }^{1} \mathrm{H}$ NMR (400 MHz; DMSO$\left.d_{6}\right): \delta 12.42(2 \mathrm{H}$, br s) $, 7.09-6.97(10 \mathrm{H}, \mathrm{m}), 4.22(2 \mathrm{H}$, app d, $J=4.2$ $\mathrm{Hz}), 3.81(2 \mathrm{H}$, app d, $J=4.3 \mathrm{~Hz}) .{ }^{13} \mathrm{C}\left\{{ }^{1} \mathrm{H}\right\}$ NMR $(100 \mathrm{MHz}$; DMSO- $\left.d_{6}\right): \delta 174.0,139.3,127.9,127.7,125.9,44.5,42.6$. FTIR: $\nu_{\max }$ (ATR, film) $/ \mathrm{cm}^{-1} 3031,2931$ (br s), 1696, 1497, 1450, 1414. HRMS (ESI-): calcd for $\mathrm{C}_{18} \mathrm{H}_{15} \mathrm{O}_{4}[\mathrm{M}-\mathrm{H}]^{-}$, 295.0976; found, 295.0984. The ${ }^{1} \mathrm{H}$ and ${ }^{13} \mathrm{C}\left\{{ }^{1} \mathrm{H}\right\}$ NMR spectral data are in accordance with the values reported in the literature. ${ }^{6}$

Naphthalene-1,8-diyl(2E,2'E)-bis(3-(4-methoxphenyl)acrylate) (7b). 1,8-DHN (6) (100 mg, $0.62 \mathrm{mmol})$ was dissolved in $15 \mathrm{~mL}$ of anhydrous $\mathrm{CH}_{2} \mathrm{Cl}_{2}$ in a $100 \mathrm{~mL}$, round-bottomed flask at 23 
${ }^{\circ} \mathrm{C}$ under nitrogen. trans-4-Methoxycinnamic acid (223 mg, 1.25 $\mathrm{mmol}$ ), DCC (258 mg, $1.25 \mathrm{mmol}$ ) and DMAP (15.3 mg, 0.125 $\mathrm{mmol}$ ) were added sequentially. The resulting cloudy, heterogeneous mixture was stirred at $23{ }^{\circ} \mathrm{C}$ for $24 \mathrm{~h}$. The reaction mixture was quenched with a $10 \%(\mathrm{w} / \mathrm{v})$ aqueous solution of citric acid $(30 \mathrm{~mL})$ and $\mathrm{H}_{2} \mathrm{O}(10 \mathrm{~mL})$. The two phases were partitioned. The organic phase was washed once with brine. It was then dried over anhydrous $\mathrm{Na}_{2} \mathrm{SO}_{4}$, filtered, and concentrated under a vacuum. Purification by column chromatography $\left(\mathrm{SiO}_{2}\right.$; only $\left.\mathrm{CH}_{2} \mathrm{Cl}_{2}\right)$ afforded pure $7 \mathbf{b}(250$ $\mathrm{mg}, 87 \%)$ as a pale yellow solid. $\mathrm{Mp}: 231-232{ }^{\circ} \mathrm{C}\left(\mathrm{CHCl}_{3}\right) . R_{f}=0.50$ (only $\mathrm{CH}_{2} \mathrm{Cl}_{2}$ ). ${ }^{1} \mathrm{H}$ NMR (400 MHz; $\mathrm{CDCl}_{3}$ ): $\delta 7.81(2 \mathrm{H}, \mathrm{d}, J=7.7$ $\mathrm{Hz}), 7.79(2 \mathrm{H}, \mathrm{d}, J=15.9 \mathrm{~Hz}), 7.49(2 \mathrm{H}, \mathrm{t}, J=7.9 \mathrm{~Hz}), 7.23(4 \mathrm{H}, \mathrm{d}, J$ $=8.7 \mathrm{~Hz}), 7.19(2 \mathrm{H}, \mathrm{d}, J=7.5 \mathrm{~Hz}), 6.64(4 \mathrm{H}, \mathrm{d}, J=8.7 \mathrm{~Hz}), 6.48$ $(2 \mathrm{H}, \mathrm{d}, J=16.0 \mathrm{~Hz}), 3.79(6 \mathrm{H}, \mathrm{s}) .{ }^{13} \mathrm{C}\left\{{ }^{1} \mathrm{H}\right\}$ NMR $(100 \mathrm{MHz}$; $\left.\mathrm{CDCl}_{3}\right): \delta 166.4,161.6,146.6,145.5,136.9,130.0,126.9,126.8$, 126.2, 121.7, 120.8, 114.9, 114.3, 55.3. FTIR: $\nu_{\max }$ (ATR, film)/ $\mathrm{cm}^{-1} 2923,2842,1718,1633,1601,1572,1513$. HRMS (ESI+): calcd for $\mathrm{C}_{30} \mathrm{H}_{24} \mathrm{O}_{6} \mathrm{Na}[\mathrm{M}+\mathrm{Na}]^{+}$, 503.1465; found, 503.1467.

$9,10-$ B is ( $4-$ m e th ox y phen yl) - 8 a $, 9,10,10$ a tetrahydrocyclobuta[g]naphtho[1,8-bc][1,5]dioxonine-8,11dione $(8 \mathrm{~b})$. Diester $7 \mathrm{~b}(16.1 \mathrm{mg}, 0.034 \mathrm{mmol})$ was placed between two glass microscope slides as a solid powder. The sample was irradiated in a safety box using a $400 \mathrm{~W}$ broadband medium-pressure Hg lamp for $12 \mathrm{~h}$. The solid powder was mixed with a spatula to ensure homogeneity every $2 \mathrm{~h}$. The reaction was stopped at the end of $12 \mathrm{~h}$ in total. Purification by column chromatography $\left(\mathrm{SiO}_{2}\right.$; only $\mathrm{CH}_{2} \mathrm{Cl}_{2}$ ) afforded pure $\mathbf{8 b}(12.5 \mathrm{mg}, 78 \%$ ) as a yellow solid. Mp: 204-205 ${ }^{\circ} \mathrm{C} . R_{f}=0.66$ (only $\left.\mathrm{CH}_{2} \mathrm{Cl}_{2}\right) .{ }^{1} \mathrm{H} \mathrm{NMR}\left(400 \mathrm{MHz} ; \mathrm{CDCl}_{3}\right)$ : $\delta 7.80(2 \mathrm{H}, \mathrm{d}, J=8.2 \mathrm{~Hz}), 7.50(2 \mathrm{H}, \mathrm{t}, J=7.9 \mathrm{~Hz}), 7.27(2 \mathrm{H}, \mathrm{d}, J=$ $7.7 \mathrm{~Hz}), 6.93(4 \mathrm{H}, \mathrm{d}, J=8.6 \mathrm{~Hz}), 6.71(4 \mathrm{H}, \mathrm{d}, J=8.6 \mathrm{~Hz}), 4.66(2 \mathrm{H}$, app d, $J=6.0 \mathrm{~Hz}), 4.16(2 \mathrm{H}$, app d, $J=5.9 \mathrm{~Hz}), 3.71(6 \mathrm{H}, \mathrm{s})$.

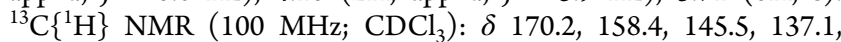
130.4, 129.0, 127.0, 126.5, 121.1, 119.7, 113.8, 55.3, 45.2, 43.7. FTIR: $\nu_{\max }\left(\right.$ ATR, film) $/ \mathrm{cm}^{-1} 2923,2842,1718,1633,1601,1513$. HRMS (ESI+): calcd for $\mathrm{C}_{30} \mathrm{H}_{24} \mathrm{O}_{6} \mathrm{Na}[\mathrm{M}+\mathrm{Na}]^{+}$, 503.1465; found, 503.1475 .

(1R,2S,3R,4S)-3,4-Bis(4-methoxyphenyl)cyclobutane-1,2-dicarboxylic Acid (meso-3b). In a $20 \mathrm{~mL}$ scintillation vial, diester $\mathbf{8 b}$ (21.7 mg, $0.045 \mathrm{mmol}$ ) was dissolved in $2.0 \mathrm{~mL}$ of THF. Afterward, distilled water $(1.0 \mathrm{~mL})$ and $\mathrm{KOH}(50 \mathrm{mg}, 0.89 \mathrm{mmol})$ were added. The resulting mixture was stirred at $23{ }^{\circ} \mathrm{C}$ for $2 \mathrm{~h}$. It was then quenched with $1.0 \mathrm{M} \mathrm{HCl}$ solution until the $\mathrm{pH}$ was adjusted to $1-2$. The aqueous phase was extracted three times with EtOAc. The combined organic phase was then dried over anhydrous $\mathrm{Na}_{2} \mathrm{SO}_{4}$, filtered, and concentrated under a vacuum. Purification by column chromatography $\left(\mathrm{SiO}_{2} ; 0.5 \%(\mathrm{v} / \mathrm{v}) \mathrm{AcOH}\right.$ in EtOAc/hexanes $\left.=1: 1\right)$ afforded pure $3 \mathrm{~b}(13.4 \mathrm{mg}, 84 \%)$ as an orange oil, and pure 1,8 -DHN (6) $\left(6.8 \mathrm{mg}, 94 \%\right.$ recovery) as a black solid. $R_{f}=0.18(0.5 \%(\mathrm{v} / \mathrm{v})$ $\mathrm{AcOH}$ in EtOAc/hexanes = 1:1). ${ }^{1} \mathrm{H}$ NMR $\left(400 \mathrm{MHz} ; \mathrm{CDCl}_{3}\right): \delta$ $10.09(2 \mathrm{H}, \mathrm{br} \mathrm{s}), 6.84(4 \mathrm{H}, \mathrm{d}, J=8.6 \mathrm{~Hz}), 6.67(4 \mathrm{H}, \mathrm{d}, J=8.7 \mathrm{~Hz})$, $4.35(2 \mathrm{H}, \mathrm{d}, J=5.8 \mathrm{~Hz}), 3.85(2 \mathrm{H}, \mathrm{d}, J=5.9 \mathrm{~Hz}), 3.71(6 \mathrm{H}, \mathrm{s})$. ${ }^{13} \mathrm{C}\left\{{ }^{1} \mathrm{H}\right\}$ NMR $\left(100 \mathrm{MHz} ; \mathrm{CDCl}_{3}\right): \delta 179.9,158.3,130.5,129.0$, 113.7, 55.3, 44.3, 44.2. FTIR: $\nu_{\max }\left(\right.$ ATR, film) $/ \mathrm{cm}^{-1} 2929$ (br s), 2837, 1704, 1611, 1513, 1424, 1248. HRMS (ESI-): calcd for $\mathrm{C}_{20} \mathrm{H}_{19} \mathrm{O}_{6}[\mathrm{M}-\mathrm{H}]^{-}$, 355.1187; found, 355.1187. The 1H-NMR spectral data are in accordance with the values reported in the literature. ${ }^{10 a}$

Naphthalene-1,8-diyl (2E,2'E)-bis(but-2-enoate) (7c). 1,8DHN (6) (100 mg, $0.62 \mathrm{mmol}$ ) was dissolved in $15 \mathrm{~mL}$ of anhydrous $\mathrm{CH}_{2} \mathrm{Cl}_{2}$ in a $100 \mathrm{~mL}$, round-bottomed flask at $23{ }^{\circ} \mathrm{C}$ under nitrogen. Crotonic acid (108 mg, $1.25 \mathrm{mmol})$, DCC (258 mg, $1.25 \mathrm{mmol})$ and DMAP ( $15.3 \mathrm{mg}, 0.125 \mathrm{mmol}$ ) were added sequentially. The resulting cloudy, heterogeneous mixture was stirred at $23{ }^{\circ} \mathrm{C}$ for $24 \mathrm{~h}$. The reaction mixture was quenched with a $10 \%(\mathrm{w} / \mathrm{v})$ aqueous solution of citric acid $(30 \mathrm{~mL})$ and $\mathrm{H}_{2} \mathrm{O}(10 \mathrm{~mL})$. The two phases were partitioned. The organic phase was washed once with brine. It was then dried over anhydrous $\mathrm{Na}_{2} \mathrm{SO}_{4}$, filtered, and concentrated under a vacuum. Purification by column chromatography $\left(\mathrm{SiO}_{2} ; \mathrm{CH}_{2} \mathrm{Cl}_{2} /\right.$ hexanes $=1: 1)$ afforded pure $7 \mathrm{c}(158 \mathrm{mg}, 85 \%)$ as a white solid with $>96 \%$ purity. A portion of this product was further purified via recrystallization from heptane to give an analytically pure sample of 7c. $\mathrm{Mp}: 153-154{ }^{\circ} \mathrm{C}$ (heptane). $R_{f}=0.42\left(\mathrm{CH}_{2} \mathrm{Cl}_{2} /\right.$ hexanes $\left.=1: 1\right)$. ${ }^{1} \mathrm{H}$ NMR $\left(400 \mathrm{MHz} ; \mathrm{CDCl}_{3}\right): \delta 7.77(2 \mathrm{H}, \mathrm{d}, J=8.2 \mathrm{~Hz}), 7.45(2 \mathrm{H}, \mathrm{t}$, $J=7.9 \mathrm{~Hz}), 7.22-7.15(2 \mathrm{H}, \mathrm{m}), 7.12(2 \mathrm{H}, \mathrm{d}, J=7.7 \mathrm{~Hz}), 6.04(2 \mathrm{H}$, app dd, $J=15.6,1.6 \mathrm{~Hz}), 1.96(6 \mathrm{H}, \mathrm{dd}, J=6.9,1.5 \mathrm{~Hz}) .{ }^{13} \mathrm{C}\left\{{ }^{1} \mathrm{H}\right\}$ NMR $\left(100 \mathrm{MHz} ; \mathrm{CDCl}_{3}\right): \delta 165.3,147.0,145.3,136.9,126.9,126.1$, 122.6, 121.6, 120.6, 18.3. FTIR: $\nu_{\max }(\mathrm{ATR}, \mathrm{film}) / \mathrm{cm}^{-1} 3057,2922$, 2850, 1742, 1659, 1603, 1442, 1377, 1312. HRMS (ESI+): calcd for $\mathrm{C}_{18} \mathrm{H}_{16} \mathrm{O}_{4} \mathrm{Na}[\mathrm{M}+\mathrm{Na}]^{+}$, 319.0941; found, 319.0940 .

Irradiation of Diester 7c. Diester $7 \mathrm{c}(23 \mathrm{mg}, 0.078 \mathrm{mmol})$ was placed between two glass microscope slides as a solid powder. The sample was irradiated in a safety box using a $400 \mathrm{~W}$ broadband medium-pressure $\mathrm{Hg}$ lamp for $4 \mathrm{~h}$. The solid powder was mixed with a spatula to ensure homogeneity after $2 \mathrm{~h}$. At the end of $4 \mathrm{~h}$ in total, the sample was transferred to a vial by washing with $\mathrm{CDCl}_{3} .{ }^{1} \mathrm{H} \mathrm{NMR}$ spectroscopic analysis indicated no formation of the desired cyclobutane product, and the reactant $7 \mathrm{c}$ was observed to remain intact. The same result was obtained when quartz microscope slides were used.

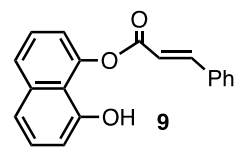

8-Hydroxynaphthalen-1-yl Cinnamate (9). In a $100 \mathrm{~mL}$ round-bottomed flask, trans-cinnamic acid $(520 \mathrm{mg}, 3.51 \mathrm{mmol})$ was dissolved in $2 \mathrm{~mL}$ of oxalyl chloride at $23{ }^{\circ} \mathrm{C}$ under an inert atmosphere of nitrogen. The clear solution was heated in an oil bath at $60{ }^{\circ} \mathrm{C}$ for $2 \mathrm{~h}$. Afterward, it was cooled back to an ambient temperature, and the volatiles were removed by the use of a rotary evaporator to give trans-cinnamoyl chloride $(575 \mathrm{mg}, 99 \%)$ as a yellow solid. In another $100 \mathrm{~mL}$ round-bottomed flask, 1,8-DHN (6, $500 \mathrm{mg}, 3.12 \mathrm{mmol}$ ) was dissolved in $10 \mathrm{~mL}$ of anhydrous THF under an inert atmosphere of nitrogen. The clear solution was cooled to 0 ${ }^{\circ} \mathrm{C}$ in an ice bath, and $\mathrm{NaH}(137 \mathrm{mg}, 3.43 \mathrm{mmol}, 60 \%$ dispersion in mineral oil) was added carefully in portions. The reaction mixture was stirred at this temperature for $20 \mathrm{~min}$. trans-Cinnamoyl chloride (520 $\mathrm{mg}$, $3.12 \mathrm{mmol}$ ), which was prepared as described above, was dissolved in $5 \mathrm{~mL}$ of anhydrous THF, and this solution was added slowly via syringe to the reaction mixture at $0{ }^{\circ} \mathrm{C}$. Afterward, the reaction mixture was stirred at $23{ }^{\circ} \mathrm{C}$ for $75 \mathrm{~min}$. TLC analysis indicated full consumption of $1,8-\mathrm{DHN}(6)$. The reaction mixture was quenched with $50 \mathrm{~mL}$ of saturated aqueous $\mathrm{NH}_{4} \mathrm{Cl}$ solution. The aqueous phase was extracted three times with $\mathrm{CH}_{2} \mathrm{Cl}_{2}$. The combined organic phase was dried over anhydrous $\mathrm{Na}_{2} \mathrm{SO}_{4}$, filtered, and concentrated under a vacuum. Purification by column chromatography $\left(\mathrm{SiO}_{2} ; \mathrm{EtOAc} /\right.$ hexanes $\left.=1: 5\right)$ afforded pure $9(740 \mathrm{mg}, 82 \%)$ as an orange solid. $\mathrm{Mp}: 119-120{ }^{\circ} \mathrm{C}\left(\mathrm{CHCl}_{3}\right) \cdot R_{f}=0.27$ (EtOAc/ hexanes $=1: 5) .{ }^{1} \mathrm{H}$ NMR $\left(400 \mathrm{MHz} ; \mathrm{CDCl}_{3}\right): \delta 7.91(1 \mathrm{H}, \mathrm{d}, J=16.0$ $\mathrm{Hz}), 7.67(1 \mathrm{H}, \mathrm{t}, J=8.3 \mathrm{~Hz}), 7.56-7.54(2 \mathrm{H}, \mathrm{m}), 7.41-7.37(5 \mathrm{H}$, m), 7.30-7.28 (2H, m), 7.20 (1H, d, $J=7.3 \mathrm{~Hz}), 6.82(1 \mathrm{H}, \mathrm{d}, J=7.6$ $\mathrm{Hz}), 6.68(1 \mathrm{H}, \mathrm{d}, J=15.9 \mathrm{~Hz}) \cdot{ }^{13} \mathrm{C}\left\{{ }^{1} \mathrm{H}\right\} \operatorname{NMR}\left(100 \mathrm{MHz} ; \mathrm{CDCl}_{3}\right): \delta$ $164.7,152.1,148.2,146.2,137.0,133.9,131.3,129.2,128.6,127.2$, 126.6, 125.6, 120.4, 118.6, 117.2, 116.5, 111.5. FTIR: $\nu_{\max }$ (ATR, film) $/ \mathrm{cm}^{-1} 3388$ (br s), 3058, 2924, 2853, 1704, 1633, 1601, 1579, 1449. HRMS (ESI+): calcd for $\mathrm{C}_{19} \mathrm{H}_{14} \mathrm{O}_{3} \mathrm{Na}[\mathrm{M}+\mathrm{Na}]^{+}, 313.0835$; found, 313.0839 .

8 - (Cinna moyloxy) naph thalen - 1 - yl - (E) - 3 - ( 4 (trifluoromethyl)phenyl)acrylate (7d). Monoester $9(100 \mathrm{mg}$, $0.35 \mathrm{mmol}$ ) was dissolved in $10 \mathrm{~mL}$ of anhydrous $\mathrm{CH}_{2} \mathrm{Cl}_{2}$ in a 100 $\mathrm{mL}$, round-bottomed flask at $23{ }^{\circ} \mathrm{C}$ under nitrogen. 4-Trifluoromethylcinnamic acid $(75 \mathrm{mg}, 0.35 \mathrm{mmol})$, DCC (72 $\mathrm{mg}, 0.35$ mmol) and DMAP $(4.2 \mathrm{mg}, 0.035 \mathrm{mmol})$ were added sequentially. The resulting orange, heterogeneous mixture was stirred at $23{ }^{\circ} \mathrm{C}$ for $24 \mathrm{~h}$. The reaction mixture was quenched with a $10 \%(\mathrm{w} / \mathrm{v})$ aqueous solution of citric acid $(30 \mathrm{~mL})$. The aqueous phase was extracted with $\mathrm{CH}_{2} \mathrm{Cl}_{2}(3 \times 30 \mathrm{~mL})$. The combined organic phase was then dried over anhydrous $\mathrm{Na}_{2} \mathrm{SO}_{4}$, filtered, and concentrated under a vacuum. Purification by column chromatography $\left(\mathrm{SiO}_{2}\right.$; hexanes: $\mathrm{CHCl}_{3}=$ 1:5) afforded pure $7 \mathbf{d}(127 \mathrm{mg}, 76 \%)$ as a white solid. Mp: 172-173 
${ }^{\circ} \mathrm{C} . R_{f}=0.36$ (hexanes: $\left.\mathrm{CHCl}_{3}=1: 5\right) .{ }^{1} \mathrm{H} \mathrm{NMR}\left(400 \mathrm{MHz} ; \mathrm{CDCl}_{3}\right)$ : $\delta 7.85-7.79(4 \mathrm{H}, \mathrm{m}), 7.51-7.46(2 \mathrm{H}, \mathrm{m}), 7.56-7.54(2 \mathrm{H}, \mathrm{m}), 7.30-$ $7.27(4 \mathrm{H}, \mathrm{m}), 7.25-7.19(5 \mathrm{H}, \mathrm{m}), 7.07(2 \mathrm{H}, \mathrm{t}, J=7.7 \mathrm{~Hz}), 6.67(1 \mathrm{H}$, d, $J=16.1 \mathrm{~Hz}), 6.59(1 \mathrm{H}, \mathrm{d}, J=16.1 \mathrm{~Hz}) .{ }^{13} \mathrm{C}\left\{{ }^{1} \mathrm{H}\right\} \mathrm{NMR}(100 \mathrm{MHz}$; $\left.\mathrm{CDCl}_{3}\right): \delta 165.9,165.4,147.0,145.3,145.1,144.9,137.1\left(\mathrm{q},{ }^{4} J_{\mathrm{C}-\mathrm{F}}=\right.$ $1.4 \mathrm{~Hz}), 137.0,133.7,131.9\left(\mathrm{q},{ }^{2} J_{\mathrm{C}-\mathrm{F}}=33.9 \mathrm{~Hz}\right), 131.0,128.9,128.3$, $128.2,127.2,127.1,126.3,126.2,125.8\left(\mathrm{q},{ }^{3} J_{\mathrm{C}-\mathrm{F}}=3.7 \mathrm{~Hz}\right), 123.8(\mathrm{q}$, $\left.{ }^{1} J_{\mathrm{C}-\mathrm{F}}=272 \mathrm{~Hz}\right), 121.4,120.9,120.7,120.1,117.4$. FTIR: $\nu_{\max }($ ATR, film) $/ \mathrm{cm}^{-1} 3064,2925,1731,1716,1642$, 1332. HRMS (ESI+): calcd for $\mathrm{C}_{29} \mathrm{H}_{19} \mathrm{O}_{4} \mathrm{~F}_{3} \mathrm{Na}[\mathrm{M}+\mathrm{Na}]^{+}$, 511.1128; found, 511.1129.

9-Phenyl-10-(4-(trifluoromethyl)phenyl)-8a,9,10,10atetrahydrocyclobuta[ $g]$ naphtho[ $1,8-b c][1,5]$ dioxonine-8,11dione (8d). Diester $7 \mathrm{~d}(25.5 \mathrm{mg}, 0.052 \mathrm{mmol})$ was placed between two glass microscope slides as a solid powder. The sample was irradiated in a safety box using a $400 \mathrm{~W}$ broadband medium-pressure $\mathrm{Hg}$ lamp for $6.5 \mathrm{~h}$. The solid powder was mixed with a spatula to ensure homogeneity every $2 \mathrm{~h}$. At the end of $6.5 \mathrm{~h}$ in total, the sample was transferred to a vial by washing with $\mathrm{CDCl}_{3}$. ${ }^{1} \mathrm{H}$ NMR spectroscopic analysis indicated $96 \%$ conversion of diester $7 \mathrm{~d}$ to the cyclobutane product $\mathbf{8 d}$. Purification by column chromatography $\left(\mathrm{SiO}_{2}\right.$; only $\left.\mathrm{CH}_{2} \mathrm{Cl}_{2}\right)$ afforded pure $8 \mathrm{~d}(22.5 \mathrm{mg}, 88 \%)$ as a white solid. Mp: $86-87{ }^{\circ} \mathrm{C}\left(\mathrm{CHCl}_{3}\right) . R_{f}=0.43$ (hexanes: $\left.\mathrm{CH}_{2} \mathrm{Cl}_{2}=1: 1\right) .{ }^{1} \mathrm{H}$ NMR (400 MHz; $\left.\mathrm{CDCl}_{3}\right): \delta 7.83(2 \mathrm{H}, \mathrm{d}, J=8.3 \mathrm{~Hz}), 7.52(2 \mathrm{H}, \mathrm{t}, J=$ $7.9 \mathrm{~Hz}), 7.42(2 \mathrm{H}, \mathrm{d}, J=8.1 \mathrm{~Hz}), 7.29(2 \mathrm{H}, \mathrm{d}, J=7.4 \mathrm{~Hz}), 7.21-7.17$ $(2 \mathrm{H}, \mathrm{m}), 7.15-7.11(3 \mathrm{H}, \mathrm{m}), 7.02(2 \mathrm{H}, \mathrm{d}, J=7.3 \mathrm{~Hz}), 4.86-4.78$ $(2 \mathrm{H}, \mathrm{m}), 4.27-4.22(2 \mathrm{H}, \mathrm{m}) .{ }^{13} \mathrm{C}\left\{{ }^{1} \mathrm{H}\right\}$ NMR $\left(100 \mathrm{MHz} ; \mathrm{CDCl}_{3}\right): \delta$ $169.83,169.79,145.4,142.4,137.6,137.1,128.6,128.4,128.3,128.0$, $127.9,127.22,127.20,127.17,126.6,126.5,125.3\left(\mathrm{q},{ }^{3} J_{\mathrm{C}-\mathrm{F}}=3.7 \mathrm{~Hz}\right)$, $121.11,121.06,44.9,44.7,44.2,44.1$ (Since the aromatic region is very crowded, the two quartet signals with ${ }^{13} \mathrm{C}-{ }^{19} \mathrm{~F}$ couplings could not be identified with certainty). FTIR: $\nu_{\max }($ ATR, film $) / \mathrm{cm}^{-1} 3062$, 2928, 1761, 1607, 1578, 1365, 1324. HRMS (ESI+): calcd for $\mathrm{C}_{29} \mathrm{H}_{19} \mathrm{~F}_{3} \mathrm{O}_{4} \mathrm{Na}[\mathrm{M}+\mathrm{Na}]^{+}$, 511.1128; found, 511.1126.

(1R,2S,3R,4S)-3-Phenyl-4-(4-(trifluoromethyl)phenyl)cyclobutane-1,2-dicarboxylic Acid (rac-3d). In a $20 \mathrm{~mL}$ scintillation vial, diester $\mathbf{8 d}(38.5 \mathrm{mg}, 0.079 \mathrm{mmol})$ was dissolved in $2.0 \mathrm{~mL}$ of THF. Afterward, distilled water $(1.0 \mathrm{~mL})$ and $\mathrm{KOH}(84$ $\mathrm{mg}, 1.50 \mathrm{mmol}$ ) were added. The resulting mixture was stirred at 23 ${ }^{\circ} \mathrm{C}$ for $2 \mathrm{~h}$. It was then quenched with $1.0 \mathrm{M} \mathrm{HCl}$ solution until the $\mathrm{pH}$ was adjusted to $1-2$. The aqueous phase was extracted three times with EtOAc. The combined organic phase was then dried over anhydrous $\mathrm{Na}_{2} \mathrm{SO}_{4}$, filtered, and concentrated under a vacuum. Purification by column chromatography $\left(\mathrm{SiO}_{2}\right.$; first EtOAc/hexanes $=$ $1: 1$; then $0.5 \%(\mathrm{v} / \mathrm{v}) \mathrm{AcOH}$ in EtOAc/hexanes = 1:1) afforded pure $3 \mathrm{~d}(22.8 \mathrm{mg}, 79 \%)$ as a white solid with a brown tinge. Mp: $123-126$ ${ }^{\circ} \mathrm{C}\left(\mathrm{CHCl}_{3}\right) \cdot R_{f}=0.23(0.5 \%(\mathrm{v} / \mathrm{v}) \mathrm{AcOH}$ in EtOAc/hexanes $=1: 1)$. ${ }^{1} \mathrm{H}$ NMR (400 MHz; DMSO- $\left.d_{6}\right): \delta 12.54(2 \mathrm{H}, \mathrm{br} \mathrm{s}), 7.42(2 \mathrm{H}, \mathrm{d}, J=$ $8.0 \mathrm{~Hz}), 7.26(2 \mathrm{H}, \mathrm{d}, J=8.0 \mathrm{~Hz}), 7.11-6.99(5 \mathrm{H}, \mathrm{m}), 4.35(1 \mathrm{H}, \mathrm{app}$ $\mathrm{t}, J=8.8 \mathrm{~Hz}), 4.22(1 \mathrm{H}, \mathrm{dd}, J=10.1,6.5 \mathrm{~Hz}), 3.92(1 \mathrm{H}$, app t, $J=8.7$ $\mathrm{Hz}), 3.78(1 \mathrm{H}, \mathrm{dd}, J=9.8,6.6 \mathrm{~Hz}) .{ }^{13} \mathrm{C}\left\{{ }^{1} \mathrm{H}\right\}$ NMR $(100 \mathrm{MHz}$; DMSO- $\left.d_{6}\right): \delta 173.9,173.7,144.3,138.9,128.6,127.9,127.8,126.5$ $\left(\mathrm{q},{ }^{2} J_{\mathrm{C}-\mathrm{F}}=31.8 \mathrm{~Hz}\right), 126.1,124.4\left(\right.$ app d, $\left.{ }^{3} J_{\mathrm{C}-\mathrm{F}}=3.6 \mathrm{~Hz}\right), 124.2(\mathrm{q}$, $\left.{ }^{1} J_{\mathrm{C}-\mathrm{F}}=271.8 \mathrm{~Hz}\right), 44.5,44.2,42.7,42.1 .{ }^{19} \mathrm{~F}\left\{{ }^{1} \mathrm{H}\right\}$ NMR $(376 \mathrm{MHz}$; DMSO- $d_{6}$ ): $\delta-59.0$ (s). FTIR: $\nu_{\max }(\mathrm{ATR}, \mathrm{film}) / \mathrm{cm}^{-1} 3030,2926$, $1707,1619,1423,1326$. HRMS (ESI-): calcd for $\mathrm{C}_{19} \mathrm{H}_{14} \mathrm{~F}_{3} \mathrm{O}_{4}[\mathrm{M}-$ $\mathrm{H}]^{-}$, 363.0850; found, 363.0847.

8 - ( Cinnamoyloxy) naphthalen-1 - yl- $(E)$ - 3 - ( 4 methoxyphenyl)acrylate (7e). Monoester 9 (100 mg, $0.35 \mathrm{mmol})$ was dissolved in $10 \mathrm{~mL}$ of anhydrous $\mathrm{CH}_{2} \mathrm{Cl}_{2}$ in a $100 \mathrm{~mL}$, roundbottomed flask at $23{ }^{\circ} \mathrm{C}$ under nitrogen. 4-Methoxycinnamic acid (61 $\mathrm{mg}, 0.35 \mathrm{mmol}), \mathrm{DCC}(72 \mathrm{mg}, 0.35 \mathrm{mmol}$ ) and DMAP (4.2 $\mathrm{mg}$, $0.035 \mathrm{mmol}$ ) were added sequentially. The resulting orange, heterogeneous mixture was stirred at $23{ }^{\circ} \mathrm{C}$ for $24 \mathrm{~h}$. The reaction mixture was quenched with a $10 \%(\mathrm{w} / \mathrm{v})$ aqueous solution of citric acid $(30 \mathrm{~mL})$. The aqueous phase was extracted three times with $\mathrm{CH}_{2} \mathrm{Cl}_{2}$. The combined organic phase was then dried over anhydrous $\mathrm{Na}_{2} \mathrm{SO}_{4}$, filtered, and concentrated under a vacuum. Purification by column chromatography $\left(\mathrm{SiO}_{2}\right.$; hexanes: $\left.\mathrm{CHCl}_{3}=1: 2\right)$ afforded pure $7 \mathrm{e}(110 \mathrm{mg}, 66 \%)$ as a pale yellow solid. $\mathrm{Mp}: 130-131{ }^{\circ} \mathrm{C} . R_{f}=0.53$ (hexanes: $\left.\mathrm{CHCl}_{3}=1: 2\right) .{ }^{1} \mathrm{H} \mathrm{NMR}\left(400 \mathrm{MHz} ; \mathrm{CDCl}_{3}\right): \delta 7.87-7.79$
$(4 \mathrm{H}, \mathrm{m}), 7.49(2 \mathrm{H}$ app t, $J=7.9 \mathrm{~Hz}), 7.31-7.28(3 \mathrm{H}, \mathrm{m}), 7.24(2 \mathrm{H}$, d, $J=7.9 \mathrm{~Hz}), 7.21-7.19(2 \mathrm{H}, \mathrm{m}), 7.15(2 \mathrm{H}, \mathrm{t}, J=7.6 \mathrm{~Hz}), 6.64-$ $6.60(3 \mathrm{H}, \mathrm{m}), 6.48(1 \mathrm{H}, \mathrm{d}, J=16.0 \mathrm{~Hz}), 3.78(3 \mathrm{H}, \mathrm{s}) .{ }^{13} \mathrm{C}\left\{{ }^{1} \mathrm{H}\right\} \mathrm{NMR}$ $\left(100 \mathrm{MHz} ; \mathrm{CDCl}_{3}\right): \delta 166.3,166.0,161.7,146.9,146.8,145.40$, $145.36,136.9,134.0,130.5,130.0,128.9,128.3,127.0,126.9,126.7$, 126.2, 126.1, 121.6, 120.8, 120.7, 117.5, 114.8, 114.4, 55.4. FTIR: $\nu_{\max }$ (ATR, film) $/ \mathrm{cm}^{-1} 2926,1732,1634,1602,1512$. HRMS (ESI+): calcd for $\mathrm{C}_{29} \mathrm{H}_{22} \mathrm{O}_{5} \mathrm{Na}[\mathrm{M}+\mathrm{Na}]^{+}, 473.1359$; found, 473.1360.

9-(4-Methoxyphenyl)- 10 - phenyl-8a, $9,10,10 a-$ tetrahydrocyclobuta[g]naphtho[1,8-bc][1,5]dioxonine-8,11dione (8e). Diester $7 \mathrm{e}(19.6 \mathrm{mg}, 0.044 \mathrm{mmol})$ was placed between two glass microscope slides as a solid powder. The sample was irradiated in a safety box using a $400 \mathrm{~W}$ broadband medium-pressure $\mathrm{Hg}$ lamp for $8 \mathrm{~h}$. The solid powder was mixed with a spatula to ensure homogeneity every $2 \mathrm{~h}$. At the end of $8 \mathrm{~h}$ in total, the sample was transferred to a vial by washing with $\mathrm{CDCl}_{3} .{ }^{1} \mathrm{H}$ NMR spectroscopic analysis indicated full conversion of diester $7 \mathbf{e}$ to the cyclobutane product 8e. Cyclobutane 8e was obtained as an orange solid upon removal of the solvent (19.4 mg, 99\%). Mp: $177-178{ }^{\circ} \mathrm{C} . R_{f}=0.62$ $($ EtOAc/hexanes $=1: 2) .{ }^{1} \mathrm{H}$ NMR $\left(400 \mathrm{MHz} ; \mathrm{CDCl}_{3}\right): \delta 7.81(2 \mathrm{H}$, $\mathrm{d}, J=8.3 \mathrm{~Hz}), 7.50(2 \mathrm{H}, \mathrm{t}, J=7.8 \mathrm{~Hz}), 7.27(2 \mathrm{H}, \mathrm{d}, J=7.4 \mathrm{~Hz}), 7.18$ $(2 \mathrm{H}, \mathrm{t}, J=7.1 \mathrm{~Hz}), 7.11(1 \mathrm{H}, \mathrm{t}, J=7.3 \mathrm{~Hz}), 7.02(2 \mathrm{H}, \mathrm{d}, J=7.4 \mathrm{~Hz})$, $6.93(2 \mathrm{H}, \mathrm{d}, J=8.3 \mathrm{~Hz}), 6.70(2 \mathrm{H}, \mathrm{d}, J=8.4 \mathrm{~Hz}), 4.76-4.68(2 \mathrm{H}$, m), $4.24(1 \mathrm{H}, \mathrm{dd}, J=10.3,5.4 \mathrm{~Hz}), 4.16(1 \mathrm{H}, \mathrm{dd}, J=10.6,5.4 \mathrm{~Hz})$, $3.72(3 \mathrm{H}, \mathrm{s}) .{ }^{13} \mathrm{C}\left\{{ }^{1} \mathrm{H}\right\}$ NMR $\left(100 \mathrm{MHz} ; \mathrm{CDCl}_{3}\right): \delta 170.2,158.4$, $145.5,138.3,137.1,129.1,128.4,128.0,127.0,126.8,126.5,121.1$, 119.7, 113.8, 55.3, 45.4, 44.7, 44.3, 43.7. FTIR: $\nu_{\max }$ (ATR, film)/ $\mathrm{cm}^{-1} 2930,1764,1608,1514,1365$. HRMS (ESI+): calcd for $\mathrm{C}_{29} \mathrm{H}_{22} \mathrm{O}_{5} \mathrm{Na}[\mathrm{M}+\mathrm{Na}]^{+}$, 473.1359; found, 473.1373 .

(1S,2R,3S,4R)-3-(4-Methoxyphenyl)-4-phenylcyclobutane1,2-dicarboxylic Acid (rac-3e). In a $20 \mathrm{~mL}$ scintillation vial, diester $8 \mathrm{e}(18.4 \mathrm{mg}, 0.041 \mathrm{mmol})$ was dissolved in $2.0 \mathrm{~mL}$ of THF. Afterward, distilled water $(1.0 \mathrm{~mL})$ and $\mathrm{KOH}(44 \mathrm{mg}, 0.78 \mathrm{mmol})$ were added. The resulting mixture was stirred at $23^{\circ} \mathrm{C}$ for $2 \mathrm{~h}$. It was then quenched with $1.0 \mathrm{M} \mathrm{HCl}$ solution until the $\mathrm{pH}$ was adjusted to $1-2$. The aqueous phase was extracted three times with EtOAc. The combined organic phase was then dried over anhydrous $\mathrm{Na}_{2} \mathrm{SO}_{4}$, filtered, and concentrated under a vacuum. Purification by column chromatography $\left(\mathrm{SiO}_{2} ; 0.5 \%(\mathrm{v} / \mathrm{v}) \mathrm{AcOH}\right.$ in EtOAc/hexanes = 1:1) afforded pure $3 \mathrm{e}(12.2 \mathrm{mg}, 91 \%)$ as a brown oil, and pure $1,8-\mathrm{DHN}$ (6) $\left(5.9 \mathrm{mg}, 91 \%\right.$ recovery) as a black solid. $R_{f}=0.21(0.5 \%(\mathrm{v} / \mathrm{v})$ $\mathrm{AcOH}$ in EtOAc/hexanes = 1:1). ${ }^{1} \mathrm{H}$ NMR $\left(400 \mathrm{MHz} ; \mathrm{CDCl}_{3}\right): \delta$ $11.31(2 \mathrm{H}, \mathrm{br} \mathrm{s}), 7.15(2 \mathrm{H}, \mathrm{t}, J=7.2 \mathrm{~Hz}), 7.08(1 \mathrm{H}, \mathrm{t}, J=7.2 \mathrm{~Hz})$, $6.94(2 \mathrm{H}, \mathrm{d}, J=7.2 \mathrm{~Hz}), 6.85(2 \mathrm{H}, \mathrm{d}, J=8.5 \mathrm{~Hz}), 6.66(2 \mathrm{H}, \mathrm{d}, J=8.6$ $\mathrm{Hz}), 4.45-4.38(2 \mathrm{H}, \mathrm{m}), 3.94(1 \mathrm{H}, \mathrm{dd}, J=9.8,5.4 \mathrm{~Hz}), 3.86(1 \mathrm{H}, \mathrm{dd}$, $J=9.8,5.4 \mathrm{~Hz}), 3.70(3 \mathrm{H}, \mathrm{s}) .{ }^{13} \mathrm{C}\left\{{ }^{1} \mathrm{H}\right\} \mathrm{NMR}\left(100 \mathrm{MHz} \mathrm{CDCl}_{3}\right): \delta$ $179.9,179.8,158.3,138.3,130.4,129.0,128.3,127.9,126.7,113.7$, 55.3, 44.8, 44.34, 44.29, 43.7. FTIR: $\nu_{\max }\left(\right.$ ATR, film) $/ \mathrm{cm}^{-1} 3030$, 2923 (br s), 2851, 1704, 1611, 1514, 1424, 1248. HRMS (ESI-): calcd for $\mathrm{C}_{19} \mathrm{H}_{17} \mathrm{O}_{5}[\mathrm{M}-\mathrm{H}]^{-}$, 325.1081; found, 325.1071.

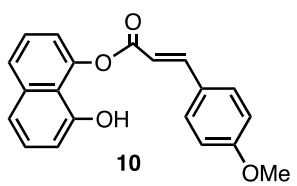

8-Hydroxynaphthalen-1-yl-(E)-3-(4-methoxyphenyl)acrylate (10). In a $50 \mathrm{~mL}$ round-bottomed flask, trans-4methoxycinnamic acid $(1.00 \mathrm{~g}, 5.61 \mathrm{mmol})$ was dissolved in $2 \mathrm{~mL}$ of oxalyl chloride at $23{ }^{\circ} \mathrm{C}$ under an inert atmosphere of nitrogen. The clear solution was heated in an oil bath at $60^{\circ} \mathrm{C}$ for $2 \mathrm{~h}$. Afterward, it was cooled back to ambient temperature, and the volatiles were removed by the use of a rotary evaporator to give trans-4methoxycinnamoyl chloride (1.104 g, 99\%) as yellow solid. In another $100 \mathrm{~mL}$ round-bottomed flask, 1,8-DHN $(6,900 \mathrm{mg}, 5.61$ mmol) was dissolved in $10 \mathrm{~mL}$ of anhydrous THF under an inert atmosphere of nitrogen. The clear solution was cooled to $0{ }^{\circ} \mathrm{C}$ in an ice bath, and $\mathrm{NaH}(247 \mathrm{mg}, 6.18 \mathrm{mmol}, 60 \%$ dispersion in mineral oil) was added carefully in portions. The reaction mixture was stirred at this temperature for $20 \mathrm{~min}$. trans-4-Methoxycinnamoyl chloride $(1.104 \mathrm{~g}, 5.61 \mathrm{mmol})$, which was prepared as described above, was 
dissolved in $10 \mathrm{~mL}$ of anhydrous THF, and this solution was added slowly via syringe to the reaction mixture at $0{ }^{\circ} \mathrm{C}$. Afterward, the reaction mixture was stirred at $23{ }^{\circ} \mathrm{C}$ for $2 \mathrm{~h}$. The reaction mixture was quenched with $50 \mathrm{~mL}$ of saturated aqueous $\mathrm{NH}_{4} \mathrm{Cl}$ solution and $10 \mathrm{~mL}$ of brine. The aqueous phase was extracted with $\mathrm{CH}_{2} \mathrm{Cl}_{2}(3 \times$ $50 \mathrm{~mL}$ ). The combined organic phase was dried over anhydrous $\mathrm{Na}_{2} \mathrm{SO}_{4}$, filtered, and concentrated under a vacuum. Purification by column chromatography $\left(\mathrm{SiO}_{2} ; \mathrm{CH}_{2} \mathrm{Cl}_{2} /\right.$ hexanes $=1: 1 \rightarrow \mathrm{CH}_{2} \mathrm{Cl}_{2} /$ hexanes $=2: 1 \rightarrow$ only $\left.\mathrm{CH}_{2} \mathrm{Cl}_{2}\right)$ afforded pure $10(1.450 \mathrm{~g}, 81 \%)$ as an orange solid. $\mathrm{Mp}: 151-152{ }^{\circ} \mathrm{C} . R_{f}=0.50$ (only $\mathrm{CH}_{2} \mathrm{Cl}_{2}$ ). ${ }^{1} \mathrm{H}$ NMR $\left(400 \mathrm{MHz} ; \mathrm{CDCl}_{3}\right): \delta 7.90(1 \mathrm{H}, \mathrm{d}, J=15.9 \mathrm{~Hz}), 7.70(1 \mathrm{H}, \mathrm{d}, J=8.2$ $\mathrm{Hz}), 7.55-7.52(3 \mathrm{H}, \mathrm{m}), 7.44-7.40(2 \mathrm{H}, \mathrm{m}), 7.32(1 \mathrm{H}, \mathrm{t}, J=7.9$ $\mathrm{Hz}), 7.23(1 \mathrm{H}, \mathrm{d}, J=7.9 \mathrm{~Hz}), 6.93(2 \mathrm{H}, \mathrm{d}, J=8.7 \mathrm{~Hz}), 6.87(1 \mathrm{H}, \mathrm{d}, J$ $=7.5 \mathrm{~Hz}), 6.57(1 \mathrm{H}, \mathrm{d}, J=15.9 \mathrm{~Hz}), 3.85(3 \mathrm{H}, \mathrm{s}) .{ }^{13} \mathrm{C}\left\{{ }^{1} \mathrm{H}\right\} \mathrm{NMR}$ $\left(100 \mathrm{MHz} ; \mathrm{CDCl}_{3}\right): \delta 164.8,162.3,152.3,148.1,146.2,137.0,130.5$, $127.3,126.7,126.5,125.6,120.3,118.5,117.1,114.7,113.6,111.5$, 55.6. FTIR: $\nu_{\max }\left(\right.$ ATR, film) $/ \mathrm{cm}^{-1} 3391$ (br s), 3057, 2838, 1707, 1633, 1601, 1512. HRMS (ESI-): calcd for $\mathrm{C}_{20} \mathrm{H}_{15} \mathrm{O}_{4}[\mathrm{M}-\mathrm{H}]^{-}$, 319.0976; found, 319.0979 .

8-(((E)-3-(4-Methoxyphenyl)acryloyl)oxy)naphthalen-1-yl (E)-3-(4-(trifluoromethyl)phenyl)acrylate (7f). Monoester 10 $(100 \mathrm{mg}, 0.31 \mathrm{mmol}$ ) was dissolved in $15 \mathrm{~mL}$ of anhydrous $\mathrm{CH}_{2} \mathrm{Cl}_{2}$ in a $100 \mathrm{~mL}$, round-bottomed flask at $23{ }^{\circ} \mathrm{C}$ under nitrogen. 4-Trifluoromethylcinnamic acid $(68 \mathrm{mg}, 0.31 \mathrm{mmol})$, DCC $(64 \mathrm{mg}$, $0.31 \mathrm{mmol})$ and DMAP $(3.8 \mathrm{mg}, 0.031 \mathrm{mmol})$ were added sequentially. The resulting pale yellow, heterogeneous mixture was stirred at $23{ }^{\circ} \mathrm{C}$ for $24 \mathrm{~h}$. The reaction mixture was quenched with 10 $\mathrm{mL}$ of water and $10 \mathrm{~mL}$ of brine. The aqueous phase was extracted with $\mathrm{CH}_{2} \mathrm{Cl}_{2}(3 \times 30 \mathrm{~mL})$. The combined organic phase was then dried over anhydrous $\mathrm{Na}_{2} \mathrm{SO}_{4}$, filtered, and concentrated under a vacuum. Purification by column chromatography $\left(\mathrm{SiO}_{2}\right.$; hexanes: $\mathrm{CH}_{2} \mathrm{Cl}_{2}=1: 1$ to $\left.1: 2\right)$ afforded pure $7 \mathbf{f}(107 \mathrm{mg}, 66 \%)$ as a white solid. Mp: $207.7-208.3{ }^{\circ} \mathrm{C}\left(\mathrm{CHCl}_{3}\right) \cdot R_{f}=0.45$ (hexanes: $\left.\mathrm{CH}_{2} \mathrm{Cl}_{2}=1: 2\right) .{ }^{1} \mathrm{H}$ NMR $\left(400 \mathrm{MHz} ; \mathrm{CDCl}_{3}\right): \delta 7.84-7.78(4 \mathrm{H}, \mathrm{m}), 7.51(1 \mathrm{H}, \mathrm{t}, J=7.9$ $\mathrm{Hz}), 7.50(1 \mathrm{H}, \mathrm{t}, J=7.9 \mathrm{~Hz}), 7.34(4 \mathrm{H}$, app s$), 7.21(4 \mathrm{H}$, app d, $J=$ $7.2 \mathrm{~Hz}), 6.70(1 \mathrm{H}, \mathrm{d}, J=16.1 \mathrm{~Hz}), 6.62(2 \mathrm{H}, \mathrm{d}, J=8.6 \mathrm{~Hz}), 6.46(1 \mathrm{H}$, $\mathrm{d}, J=16.0 \mathrm{~Hz}), 3.77(3 \mathrm{H}, \mathrm{s}) .{ }^{13} \mathrm{C}\left\{{ }^{1} \mathrm{H}\right\}$ NMR $\left(100 \mathrm{MHz} \mathrm{CDCl}_{3}\right): \delta$ $166.2,165.4,161.9,146.7,145.4,145.1,144.8,137.2,136.9,131.8$ (q, $\left.{ }^{2} J_{\mathrm{C}-\mathrm{F}}=32.3 \mathrm{~Hz}\right), 129.9,128.3,127.1,126.9,126.4,126.3,126.1$, $125.6\left(\mathrm{q},{ }^{3} J_{\mathrm{C}-\mathrm{F}}=3.7 \mathrm{~Hz}\right), 123.9\left(\mathrm{q},{ }^{1} J_{\mathrm{C}-\mathrm{F}}=272.2 \mathrm{~Hz}\right), 121.4,120.9$, 120.6, 120.1, 114.7, 114.3, 55.3.FTIR: $\nu_{\max }\left(\right.$ ATR, film) $/ \mathrm{cm}^{-1} 3079$, 2924, 1724, 1642,1599, 1575, 1511, 1321, 1251. HRMS (ESI+) Calcd for $\mathrm{C}_{30} \mathrm{H}_{21} \mathrm{~F}_{3} \mathrm{O}_{5} \mathrm{Na}[\mathrm{M}+\mathrm{Na}]^{+}$, 541.1233; found, 541.1255.

9-(4-Methoxyphenyl)-10-(4-(trifluoromethyl)phenyl)$8 a, 9,10,10 a$-tetrahydrocyclobuta $[g]$ naphtho[ $1,8-b c][1,5]-$ dioxonine-8,11-dione (8f). Diester $7 \mathrm{f}(25.6 \mathrm{mg}, 0.049 \mathrm{mmol})$ was placed between two glass microscope slides as a solid powder. The sample was irradiated in a safety box using a $400 \mathrm{~W}$ broadband medium-pressure $\mathrm{Hg}$ lamp for $8 \mathrm{~h}$. The solid powder was mixed with a spatula to ensure homogeneity after every $2 \mathrm{~h}$. At the end of $8 \mathrm{~h}$ in total, the sample was transferred to a vial by washing with $\mathrm{CHCl}_{3} \cdot{ }^{1} \mathrm{H}$ NMR spectroscopic analysis indicated full conversion of diester $7 \mathbf{f}$ to the cyclobutane product $8 \mathrm{f}$. The presence of diester $7 \mathrm{f}$ or any other side product was not observed in this spectrum. Cyclobutane $8 \mathrm{f}$ was obtained as a light brown amorphous solid upon removal of the solvent $(23.9 \mathrm{mg}, 93 \%) . \mathrm{Mp}: 83-85^{\circ} \mathrm{C} . R_{f}=0.44($ EtOAc $/$ hexanes $=$ 1:5). ${ }^{1} \mathrm{H}$ NMR (400 MHz; $\left.\mathrm{CDCl}_{3}\right): \delta 7.83(2 \mathrm{H}, \mathrm{d}, J=8.2 \mathrm{~Hz}), 7.52$ $(2 \mathrm{H}, \mathrm{t}, J=7.8 \mathrm{~Hz}), 7.43(2 \mathrm{H}, \mathrm{d}, J=7.8 \mathrm{~Hz}), 7.29(2 \mathrm{H}, \mathrm{d}, J=7.3 \mathrm{~Hz})$, $7.12(2 \mathrm{H}, \mathrm{d}, J=7.8 \mathrm{~Hz}), 6.93(2 \mathrm{H}, \mathrm{d}, J=8.3 \mathrm{~Hz}), 6.72(2 \mathrm{H}, \mathrm{d}, J=8.3$ $\mathrm{Hz}), 4.82-4.78(1 \mathrm{H}, \mathrm{m}), 4.76-4.72(1 \mathrm{H}, \mathrm{m}), 4.25(1 \mathrm{H}, \mathrm{dd}, J=10.4$, $6.6 \mathrm{~Hz}), 4.17(1 \mathrm{H}, \mathrm{dd}, J=10.5,6.0 \mathrm{~Hz}), 3.73(3 \mathrm{H}, \mathrm{s}) .{ }^{13} \mathrm{C}\left\{{ }^{1} \mathrm{H}\right\} \mathrm{NMR}$ $\left(100 \mathrm{MHz} ; \mathrm{CDCl}_{3}\right): \delta 169.91,169.88,158.7,145.4,142.5,137.1$, $129.7,129.1,129.0\left(\mathrm{q},{ }^{2} \mathrm{~J}_{\mathrm{C}-\mathrm{F}}=32.7 \mathrm{~Hz}\right), 128.2,127.2,127.1,126.6$, $126.5,125.3\left(\mathrm{q},{ }^{3} J_{\mathrm{C}-\mathrm{F}}=3.5 \mathrm{~Hz}\right), 124.2\left(\mathrm{q},{ }^{1} J_{\mathrm{C}-\mathrm{F}}=272.1 \mathrm{~Hz}\right), 121.10$, 121.05, 119.5, 114.0, 55.3, 45.3, 44.6, 44.1, 43.6.FTIR: $\nu_{\max }$ (ATR, film) $/ \mathrm{cm}^{-1} 3060,2928,2840,1763,1608,1580,1514,1365,1324$. HRMS (ESI+): calcd for $\mathrm{C}_{30} \mathrm{H}_{21} \mathrm{~F}_{3} \mathrm{O}_{5} \mathrm{Na}[\mathrm{M}+\mathrm{Na}]^{+}$, 541.1233; found, 541.1263.

Photochemical Reaction of $7 f$ in Heptane on a $1.0 \mathrm{mmol}$ Scale. Heptane $(250 \mathrm{~mL})$ was degassed via a flow of nitrogen and was transferred to an immersion well reactor flask containing solid diester $7 \mathrm{f}(519 \mathrm{mg}, 1.00 \mathrm{mmol})$. The resulting suspension was irradiated in a safety box using a $400 \mathrm{~W}$ broadband medium-pressure $\mathrm{Hg}$ lamp while stirring under a balloon of argon for $8 \mathrm{~h}$. During the irradiation, the suspension was cooled continuously with a flow of cold water to prevent heating of the reaction mixture. The color turned from white to orange during the reaction. At the end of $8 \mathrm{~h}$, the sample was transferred to a round-bottomed flask by washing with $\mathrm{CH}_{2} \mathrm{Cl}_{2} \cdot{ }^{1} \mathrm{H}$ NMR analysis of the crude mixture indicated full conversion to the cycloaddition product. Purification by column chromatography $\left(\mathrm{SiO}_{2}\right.$; $\mathrm{CH}_{2} \mathrm{Cl}_{2} /$ hexanes $\left.=2: 1\right)$ afforded pure $\mathbf{8 f}(431 \mathrm{mg}, 83 \%)$ as an orange solid.

(1R,2S,3R,4S)-3-(4-Methoxyphenyl)-4-(4-(trifluoromethyl)phenyl)cyclobutane-1,2-dicarboxylic Acid (rac-3f). In a $20 \mathrm{~mL}$ scintillation vial, diester $8 \mathrm{f}(23 \mathrm{mg}, 0.044 \mathrm{mmol})$ was dissolved in 2.0 $\mathrm{mL}$ of THF. Afterward, distilled water $(1.0 \mathrm{~mL})$ and $\mathrm{KOH}(47 \mathrm{mg}$, $0.84 \mathrm{mmol}$ ) were added. The resulting mixture was stirred at $23{ }^{\circ} \mathrm{C}$ for $2.5 \mathrm{~h}$. It was then quenched with $1.0 \mathrm{M} \mathrm{HCl}$ solution until the $\mathrm{pH}$ was adjusted to $1-2$. The aqueous phase was extracted three times with EtOAc. The combined organic phase was then dried over anhydrous $\mathrm{Na}_{2} \mathrm{SO}_{4}$, filtered, and concentrated under a vacuum. Purification by column chromatography $\left(\mathrm{SiO}_{2}\right.$; first EtOAc/hexanes = $1: 1$, then $0.5 \%(\mathrm{v} / \mathrm{v}) \mathrm{AcOH}$ in EtOAc/hexanes = 1:1) afforded pure 3f $(16 \mathrm{mg}, 92 \%)$ as a brownish amorphous solid, and pure 1,8-DHN (6) $(6.8 \mathrm{mg}, 97 \%$ recovery) as a black solid.

In another experiment, diester $8 \mathrm{f}(300 \mathrm{mg}, 0.58 \mathrm{mmol})$ was dissolved in $4.0 \mathrm{~mL}$ of THF in a $20 \mathrm{~mL}$ scintillation vial. Afterward, distilled water $(2.0 \mathrm{~mL})$ and $\mathrm{KOH}(618 \mathrm{mg}, 11.0 \mathrm{mmol})$ were added. The resulting mixture was stirred at $23{ }^{\circ} \mathrm{C}$ for $2 \mathrm{~h}$. It was then quenched with $1.0 \mathrm{M} \mathrm{HCl}$ solution until the $\mathrm{pH}$ was adjusted to $1-2$. The aqueous phase was extracted with EtOAc $(3 \times 20 \mathrm{~mL})$. The combined organic phase was then dried over anhydrous $\mathrm{Na}_{2} \mathrm{SO}_{4}$, filtered, and concentrated under a vacuum. Purification by column chromatography $\left(\mathrm{SiO}_{2}\right.$; first EtOAc/hexanes = 1:1, then $0.5 \%(\mathrm{v} / \mathrm{v})$ $\mathrm{AcOH}$ in EtOAc/hexanes = 1:1) afforded pure $3 \mathrm{f}(207 \mathrm{mg}, 90 \%)$ as an amorphous dark brown solid. Mp: $88-89{ }^{\circ} \mathrm{C}\left(\mathrm{CHCl}_{3}\right) \cdot R_{f}=0.14$ $\left(0.5 \%(\mathrm{v} / \mathrm{v}) \mathrm{AcOH}\right.$ in EtOAc/hexanes = 1:1). ${ }^{1} \mathrm{H}$ NMR $(400 \mathrm{MHz}$; $\left.\mathrm{CDCl}_{3}\right): \delta 10.27(2 \mathrm{H}, \mathrm{s}), 7.39(2 \mathrm{H}, \mathrm{d}, J=8.1 \mathrm{~Hz}), 7.03(2 \mathrm{H}, \mathrm{d}, J=$ $8.1 \mathrm{~Hz}), 6.84(2 \mathrm{H}, \mathrm{d}, J=8.6 \mathrm{~Hz}), 6.68(2 \mathrm{H}, \mathrm{d}, J=8.6 \mathrm{~Hz}), 4.53(1 \mathrm{H}$, app t, $J=8.8 \mathrm{~Hz}), 4.36(1 \mathrm{H}, \mathrm{dd}, J=10.0,6.1 \mathrm{~Hz}), 3.95(1 \mathrm{H}$, app t, $J=$ $8.9 \mathrm{~Hz}), 3.83(1 \mathrm{H}, \mathrm{dd}, J=10.0,6.1 \mathrm{~Hz}), 3.71(3 \mathrm{H}, \mathrm{s}) .{ }^{13} \mathrm{C}\left\{{ }^{1} \mathrm{H}\right\} \mathrm{NMR}$ $\left(100 \mathrm{MHz} ; \mathrm{CDCl}_{3}\right): \delta 179.7,179.3,158.6,142.5,129.7,128.94$, $128.92\left(\mathrm{q},{ }^{2} \mathrm{~J}_{\mathrm{C}-\mathrm{F}}=32.6 \mathrm{~Hz}\right), 128.1,125.2\left(\mathrm{q},{ }^{3} \mathrm{~J}_{\mathrm{C}-\mathrm{F}}=3.5 \mathrm{~Hz}\right), 124.2$ $\left(\mathrm{q},{ }^{1} \mathrm{~J}_{\mathrm{C}-\mathrm{F}}=272.4 \mathrm{~Hz}\right), 114.0,55.3,44.6,44.5,44.3,43.4 .{ }^{19} \mathrm{~F}\left\{{ }^{1} \mathrm{H}\right\}$ NMR (376 MHz; $\left.\mathrm{CDCl}_{3}\right): \delta-61.3$ (s). FTIR: $\nu_{\max }(\mathrm{ATR}, \mathrm{film}) / \mathrm{cm}^{-1}$ 2925 (br s), 2853, 1705, 1614, 1514, 1421, 1324. HRMS (ESI-): calcd for $\mathrm{C}_{20} \mathrm{H}_{16} \mathrm{~F}_{3} \mathrm{O}_{5}[\mathrm{M}-\mathrm{H}]^{-}$, 393.0955; found, 393.0968.

8-(Cinnamoyloxy)naphthalen-1-yl-(E)-3-(furan-2-yl)acrylate (7g). In a $50 \mathrm{~mL}$ round-bottomed flask, (E)-3-(2-furyl)acrylic acid (60 mg, $0.43 \mathrm{mmol}$ ) was dissolved in $2 \mathrm{~mL}$ of oxalyl chloride at $23^{\circ} \mathrm{C}$ under an inert atmosphere of nitrogen. The clear solution was heated in an oil bath at $60{ }^{\circ} \mathrm{C}$ for $2 \mathrm{~h}$. Afterward, it was cooled back to ambient temperature, and the volatiles were removed by the use of a rotary evaporator to give (E)-3-(2-furyl)acryloyl chloride $(64 \mathrm{mg}$, $94 \%$ ) as a pale yellow solid. In another $100 \mathrm{~mL}$ round-bottomed flask, monoester $9(100 \mathrm{mg}, 0.34 \mathrm{mmol})$ was dissolved in $10 \mathrm{~mL}$ of anhydrous THF under an inert atmosphere of nitrogen. The clear solution was cooled to $0{ }^{\circ} \mathrm{C}$ in an ice bath, and $\mathrm{NaH}$ (15.2 mg, 0.38 mmol, $60 \%$ dispersion in mineral oil) was added carefully. The resulting dark purple mixture was stirred at this temperature for 15 min. (E)-3-(2-Furyl)acryloyl chloride $(64 \mathrm{mg}, 0.41 \mathrm{mmol}$ ), which was prepared as described above, was dissolved in $5 \mathrm{~mL}$ of anhydrous THF, and this solution was added slowly via syringe to the reaction mixture at $0{ }^{\circ} \mathrm{C}$. Afterward, the reaction mixture was stirred at $23{ }^{\circ} \mathrm{C}$ for $2 \mathrm{~h}$. The reaction mixture was quenched with saturated aqueous $\mathrm{NH}_{4} \mathrm{Cl}$ solution. The aqueous phase was extracted three times with $\mathrm{CH}_{2} \mathrm{Cl}_{2}$. The combined organic phase was dried over anhydrous $\mathrm{Na}_{2} \mathrm{SO}_{4}$, filtered, and concentrated under a vacuum. Purification by column chromatography $\left(\mathrm{SiO}_{2} ; \mathrm{CH}_{2} \mathrm{Cl}_{2} /\right.$ hexanes $\left.=1: 1\right)$ afforded pure $7 \mathrm{~g}(125 \mathrm{mg}, 90 \%)$ as a brown solid. $\mathrm{Mp}: 174-176^{\circ} \mathrm{C}\left(\mathrm{CHCl}_{3}\right) \cdot R_{f}=$ 
$0.28\left(\mathrm{CH}_{2} \mathrm{Cl}_{2} /\right.$ hexanes $\left.=1: 1\right) .{ }^{1} \mathrm{H}$ NMR $\left(400 \mathrm{MHz} ; \mathrm{CDCl}_{3}\right): \delta 7.87$ $(1 \mathrm{H}, \mathrm{d}, J=16.1 \mathrm{~Hz}), 7.82(2 \mathrm{H}, \mathrm{d}, J=8.3 \mathrm{~Hz}), 7.60(1 \mathrm{H}, \mathrm{d}, J=15.7$ $\mathrm{Hz}), 7.53-7.48(2 \mathrm{H}, \mathrm{m}), 7.39-7.37(2 \mathrm{H}, \mathrm{m}), 7.34-7.31(1 \mathrm{H}, \mathrm{m})$, $7.27-7.20(4 \mathrm{H}, \mathrm{m}), 7.12(1 \mathrm{H}, \mathrm{d}, J=1.4 \mathrm{~Hz}), 6.64(1 \mathrm{H}, \mathrm{d}, J=16.0$ $\mathrm{Hz}), 6.53-6.48(2 \mathrm{H}, \mathrm{m}), 6.30(1 \mathrm{H}, \mathrm{dd}, J=3.4,1.8 \mathrm{~Hz}) .{ }^{13} \mathrm{C}\left\{{ }^{1} \mathrm{H}\right\}$ NMR $\left(100 \mathrm{MHz} ; \mathrm{CDCl}_{3}\right): \delta 166.02,165.98,150.5,147.0,145.33$, $145.31,145.26,136.9,134.2,132.9,130.5,128.9,128.3,126.95$, $126.93,126.2,121.5,120.7,117.5,115.9,115.1,112.4$. FTIR: $\nu_{\max }$ (ATR, film) $/ \mathrm{cm}^{-1} 3141,3056,1722,1631,1602,1370$. HRMS (ESI $+)$ : calcd for $\mathrm{C}_{26} \mathrm{H}_{18} \mathrm{O}_{5} \mathrm{Na}[\mathrm{M}+\mathrm{Na}]^{+}, 433.1046$; found, 433.1046.

9-(Furan-2-yl)-10-phenyl-8a,9,10,10a-tetrahydrocyclobuta[g]naphtho[1,8-bc][1,5]dioxonine-8,11-dione (8g). Diester $7 \mathrm{~g}$ $(24.7 \mathrm{mg}, 0.060 \mathrm{mmol})$ was placed between two glass microscope slides as a solid powder. The sample was irradiated in a safety box using a $400 \mathrm{~W}$ broadband medium-pressure $\mathrm{Hg}$ lamp for $8 \mathrm{~h}$. The solid powder was mixed with a spatula to ensure homogeneity every 2 $\mathrm{h}$. At the end of $8 \mathrm{~h}$ in total, the sample was transferred to a vial by washing with $\mathrm{CDCl}_{3} .{ }^{1} \mathrm{H}$ NMR spectroscopic analysis indicated almost full conversion of diester $7 \mathrm{~g}$ to the cyclobutane product $8 \mathrm{~g}$. Purification by column chromatography $\left(\mathrm{SiO}_{2} ; \mathrm{CH}_{2} \mathrm{Cl}_{2} /\right.$ hexanes $=$ 1:1) afforded pure $8 \mathrm{~g}(21.8 \mathrm{mg}, 88 \%)$ as a white solid. Mp: $149-150$ ${ }^{\circ} \mathrm{C}\left(\mathrm{CHCl}_{3}\right) . R_{f}=0.27\left(\mathrm{CH}_{2} \mathrm{Cl}_{2} /\right.$ hexanes $\left.=1: 1\right) .{ }^{1} \mathrm{H}$ NMR $(400$ $\left.\mathrm{MHz} ; \mathrm{CDCl}_{3}\right): \delta 7.80(2 \mathrm{H}, \mathrm{d}, J=8.4 \mathrm{~Hz}), 7.53-7.48(2 \mathrm{H}, \mathrm{m}), 7.29-$ $7.22(4 \mathrm{H}, \mathrm{m}), 7.19-7.17(2 \mathrm{H}, \mathrm{m}), 7.13-7.11(2 \mathrm{H}, \mathrm{m}), 6.17(1 \mathrm{H}, \mathrm{dd}$, $J=3.2,1.9 \mathrm{~Hz}), 6.03(1 \mathrm{H}, \mathrm{d}, J=3.2 \mathrm{~Hz}), 4.74(1 \mathrm{H}, \mathrm{t}, J=9.3 \mathrm{~Hz})$, $4.62(1 \mathrm{H}, \mathrm{dd}, J=10.1,4.8 \mathrm{~Hz}), 4.40(1 \mathrm{H}$, ddd, $J=10.5,8.6,0.8 \mathrm{~Hz})$, $4.20(1 \mathrm{H}, \mathrm{ddd}, J=10.6,4.8,0.9 \mathrm{~Hz}) .{ }^{13} \mathrm{C}\left\{{ }^{1} \mathrm{H}\right\}$ NMR $(100 \mathrm{MHz}$; $\left.\mathrm{CDCl}_{3}\right): \delta 170.1,169.6,152.1,145.5,145.4,142.2,138.1,137.1$, $128.3,127.3,127.09,127.06,126.99,126.5,121.2,121.0,119.6,110.4$, 108.2, 45.1, 44.3, 43.7, 38.4. FTIR: $\nu_{\max }(\mathrm{ATR}, \mathrm{film}) / \mathrm{cm}^{-1} 3060$, 3030, 2924, 1765, 1608, 1500, 1364, 1216. HRMS (ESI+): calcd for $\mathrm{C}_{26} \mathrm{H}_{18} \mathrm{O}_{5} \mathrm{Na}[\mathrm{M}+\mathrm{Na}]^{+}$, 433.1046; found, 433.1046.

(1S,2R,3S,4R)-3-(Furan-2-yl)-4-phenylcyclobutane-1,2-dicarboxylic Acid (rac-3g). In a $20 \mathrm{~mL}$ scintillation vial, diester $8 \mathrm{~g}(19.3$ $\mathrm{mg}, 0.047 \mathrm{mmol}$ ) was dissolved in $2.0 \mathrm{~mL}$ of THF. Afterward, distilled water $(1.0 \mathrm{~mL})$ and $\mathrm{KOH}(50 \mathrm{mg}, 0.89 \mathrm{mmol})$ were added. The resulting mixture was stirred at $23{ }^{\circ} \mathrm{C}$ for $2 \mathrm{~h}$. It was then quenched with $1.0 \mathrm{M} \mathrm{HCl}$ solution until the $\mathrm{pH}$ was adjusted to $1-2$. The aqueous phase was extracted with EtOAc $(3 \times 10 \mathrm{~mL})$. The combined organic phase was then dried over anhydrous $\mathrm{Na}_{2} \mathrm{SO}_{4}$, filtered, and concentrated under a vacuum. Purification by column chromatography $\left(\mathrm{SiO}_{2}\right.$; first EtOAc/hexanes $=1: 1$, then $0.5 \%(\mathrm{v} / \mathrm{v})$ $\mathrm{AcOH}$ in EtOAc/hexanes = 1:1) afforded pure $3 \mathrm{~g}(11.4 \mathrm{mg}, 84 \%)$ as a pale yellow oil and pure 1,8-DHN (6) (6.8 $\mathrm{mg}, 91 \%$ recovery) as a black solid. $R_{f}=0.17(0.5 \%(\mathrm{v} / \mathrm{v}) \mathrm{AcOH}$ in EtOAc/hexanes $=1: 1)$. ${ }^{1} \mathrm{H}$ NMR (400 MHz; $\left.\mathrm{CDCl}_{3}\right): \delta 7.20-7.12(4 \mathrm{H}, \mathrm{m}), 7.03(2 \mathrm{H}, \mathrm{d}, J=$ $7.1 \mathrm{~Hz}), 6.13(1 \mathrm{H}, \mathrm{dd}, J=3.0,1.9 \mathrm{~Hz}), 5.94(1 \mathrm{H}, \mathrm{d}, J=3.1 \mathrm{~Hz}), 4.48$ $(1 \mathrm{H}, \mathrm{t}, J=9.4 \mathrm{~Hz}), 4.24(1 \mathrm{H}, \mathrm{dd}, J=9.7,4.7 \mathrm{~Hz}), 4.13(1 \mathrm{H}, \mathrm{t}, J=9.6$ $\mathrm{Hz}), 3.84(1 \mathrm{H}, \mathrm{dd}, J=10.0,4.7 \mathrm{~Hz}) .{ }^{13} \mathrm{C}\left\{{ }^{1} \mathrm{H}\right\}$ NMR $(100 \mathrm{MHz}$; $\left.\mathrm{CDCl}_{3}\right): \delta 179.4,179.2,152.2,142.0,138.3,128.2,127.2,126.9$, 110.3, 108.1, 44.6, 43.6 (two overlapping signals), 38.9. FTIR: $\nu_{\max }$ (ATR, film) $/ \mathrm{cm}^{-1}$ 3029, 2924 (br s), 2854, 1706, 1603, 1498, 1423. HRMS (ESI-): calcd for $\mathrm{C}_{16} \mathrm{H}_{13} \mathrm{O}_{5}[\mathrm{M}-\mathrm{H}]^{-}, 285.0768$, found 285.0779.

Crystallization of 7a, 8a, and 7f for X-ray Crystallographic Analysis. Each of the compounds (7a, 8a, and $7 \mathbf{f}$; ca. $10 \mathrm{mg}$ ) was dissolved in $\mathrm{CH}_{2} \mathrm{Cl}_{2}(1.0 \mathrm{~mL})$ in a small vial, which was placed in a 20 $\mathrm{mL}$ scintillation vial containing pentane $(3 \mathrm{~mL})$. The outer vial was sealed with a screw cap and left at an ambient temperature for crystallization.

\section{ASSOCIATED CONTENT}

\section{SI Supporting Information}

The Supporting Information is available free of charge at https://pubs.acs.org/doi/10.1021/acs.joc.1c01534.

Single crystal XRD data of $7 \mathbf{a}, \mathbf{8 a}$, and $\mathbf{7 f}$, and NMR spectra for all synthesized compounds (PDF) FAIR data, including the primary NMR FID files, for compounds $3 a-3 g, 7 a-7 g, 8 a-8 g, 9$, and 10 (ZIP)

\section{Accession Codes}

CCDC 2086783-2086785 contain the supplementary crystallographic data for this paper. These data can be obtained free of charge via www.ccdc.cam.ac.uk/data_request/cif, or by emailing data_request@ccdc.cam.ac.uk, or by contacting The Cambridge Crystallographic Data Centre, 12 Union Road, Cambridge CB2 1EZ, UK; fax: +44 1223336033.

\section{AUTHOR INFORMATION}

\section{Corresponding Author}

Yunus Emre Türkmen - Department of Chemistry, Faculty of Science and UNAM, National Nanotechnology Research Center, Institute of Materials Science and Nanotechnology, Bilkent University, Ankara, Ankara 06800, Turkey; 이이.org/0000-0002-9797-2820; Email: yeturkmen@ bilkent.edu.tr

\section{Authors}

Bilge Banu Yagci - Department of Chemistry, Faculty of Science, Bilkent University, Ankara, Ankara 06800, Turkey

Yunus Zorlu - Department of Chemistry, Gebze Technical University, Gebze, Kocaeli 41400, Turkey; ○orcid.org/ 0000-0003-2811-1872

Complete contact information is available at: https://pubs.acs.org/10.1021/acs.joc.1c01534

\section{Author Contributions}

The manuscript was written through contributions of all authors. All authors have given approval to the final version of the manuscript.

Notes

The authors declare no competing financial interest.

\section{ACKNOWLEDGMENTS}

Y.E.T. acknowledges the BAGEP Award of the Science Academy, Turkey.

\section{REFERENCES}

(1) (a) Sarkar, D.; Bera, N.; Ghosh, S. [2+2] Photochemical Cycloaddition in Organic Synthesis. Eur. J. Org. Chem. 2020, 2020, 1310-1326. (b) Liu, W.; Li, C.-J. Recent Synthetic Applications of Catalyst-Free Photochemistry. Synlett 2017, 28, 2714-2754. (c) Poplata, S.; Tröster, A.; Zou, Y.-Q.; Bach, T. Recent Advances in the Synthesis of Cyclobutanes by Olefin [2+2] Photocycloaddition Reactions. Chem. Rev. 2016, 116, 9748-9815. (d) Bach, T.; Hehn, J. P. Photochemical Reactions as Key Steps in Natural Product Synthesis. Angew. Chem., Int. Ed. 2011, 50, 1000-1045. (e) Hoffmann, N. Photochemical Reactions as Key Steps in Organic Synthesis. Chem. Rev. 2008, 108, 1052-1103. (f) Iriondo-Alberdi, J.; Greaney, M. F. Photocycloaddition in Natural Product Synthesis. Eur. J. Org. Chem. 2007, 2007, 4801-4815. (g) Bach, T. Stereoselective Intermolecular $[2+2]$ Photocycloaddition Reactions and Their Application in Synthesis. Synthesis 1998, 1998, 683-703. (h) Crimmins, M. T.; Reinhold, T. L. Enone Olefin [2+2] Photochemical Cycloadditions. Org. React. 1993, 44, 297-588.

(2) Bassani, D. M. The Dimerization of Cinnamic Acid Derivatives. In CRC Handbook of Photochemistry and Photobiology, 2nd ed.; Horspool, W. M., Lenci, F., Eds.; CRC Press: Boca Raton, 2004; pp 20-1-20-20.

(3) For selected examples, see: (a) Li, J.; Tan, L.-H.; Zou, H.; Zou, Z.-X.; Long, H.-P.; Wang, W.-X.; Xu, P.-S.; Liu, L.-F.; Xu, K.-P.; Tan, G.-S. Palhinosides A-H: Flavone Glucosidic Truxinate Esters with Neuroprotective Activities from Palhinhaea cernua. J. Nat. Prod. 2020, 83, 216-222. (b) Yan, S.; Elmes, M. W.; Tong, S.; Hu, K.; Awwa, M.; Teng, G. Y. H.; Jing, Y.; Freitag, M.; Gan, Q.; Clement, T.; Wei, L.; 
Sweeney, J. M.; Joseph, O. M.; Che, J.; Carbonetti, G. S.; Wang, L.; Bogdan, D. M.; Falcone, J.; Smietalo, N.; Zhou, Y.; Ralph, B.; Hsu, H.-C.; Li, H.; Rizzo, R. C.; Deutsch, D. G.; Kaczocha, M.; Ojima, I. SAR Studies on Truxillic Acid Mono Esters as a New Class of Antinociceptive Agents Targeting Fatty Acid Binding Proteins. Eur. J. Med. Chem. 2018, 154, 233-252. (c) Fujiwara, A.; Nishi, M.; Yoshida, S.; Hasegawa, M.; Yasuma, C.; Ryo, A.; Suzuki, Y. Eucommicin A, a -Truxinate Lignan from Eucommia ulmoides, is a Selective Inhibitor of Cancer Stem Cells. Phytochemistry 2016, 122, 139-145. (d) Huang, B.; Zhang, F.; Yu, G.; Song, Y.; Wang, X.; Wang, M.; Gong, Z.; Su, R.; Jia, Y. Gram Scale Syntheses of (-)-Incarvillateine and Its Analogs. Discovery of Potent Analgesics for Neuropathic Pain. J. Med. Chem. 2016, 59, 3953-3963. (e) Berger, W. T.; Ralph, B. P.; Kaczocha, M.; Sun, J.; Balius, T. E.; Rizzo, R. C.; Haj-Dahmane, S.; Ojima, I.; Deutsch, D. G. Targeting Fatty Acid Binding Protein (FABP) Anandamide Transporters - A Novel Strategy for Development of Anti-Inflammatory and Anti-Nociceptive Drugs. PLoS One 2012, 7, No. e50968. (f) Chi, Y.-M.; Nakamura, M.; Zhao, X.-Y.; Yoshizawa, T.; Yan, W.-M.; Hashimoto, F.; Kinjo, J.; Nohara, T.; Sakurada, S. Antinociceptive Activities of tt-Truxillic Acid and -Truxinic Acid Derivatives. Biol. Pharm. Bull. 2006, 29, 580-584. (g) Monache, G. D.; Botta, B.; Monache, F. D.; Espinal, R.; De Bonnevaux, S. C.; De Luca, C.; Botta, M.; Corelli, F.; Dei, D.; Gacs-Baitz, E.; Carmignani, M. Caracasandiamide, A Truxinic Hypotensive Agent from Verbesina Caracasana. Bioorg. Med. Chem. Lett. 1996, 6, 233-238.

(4) (a) Biradha, K.; Santra, R. Crystal Engineering of Topochemical Solid State Reactions. Chem. Soc. Rev. 2013, 42, 950-967. (b) Sonoda, Y. $[2+2]$-Photocycloadditions in the Solid State. In CRC Handbook of Photochemistry and Photobiology, 2nd ed.; Horspool, W. M., Lenci, F., Eds.; CRC Press: Boca Raton, 2004; pp 73-1-73-15. (c) Schmidt, G. M. J. Photodimerization in the Solid State. Pure Appl. Chem. 1971, 27, 647-678.

(5) (a) Bernstein, H. I.; Quimby, W. C. The Photochemical Dimerization of trans-Cinnamic Acid. J. Am. Chem. Soc. 1943, 65, 1845-1846. (b) Cohen, M. D.; Schmidt, G. M. J.; Sonntag, F. I. Topochemistry. Part II. The Photochemistry of trans-Cinnamic Acids. J. Chem. Soc. 1964, 2000-2013. (c) Schmidt, G. M. J. Topochemistry. Part III. The Crystal Chemistry of Some trans-Cinnamic Acids. J. Chem. Soc. 1964, 2014-2021.

(6) Amjaour, H.; Wang, Z.; Mabin, M.; Puttkammer, J.; Busch, S.; Chu, Q. R. Scalable Preparation and Property Investigation of a cisCyclobutane-1,2-dicarboxylic Acid from $\beta$-trans-Cinnamic acid. Chem. Commun. 2019, 55, 214-217.

(7) (a) Gan, M.-M.; Yu, J.-G.; Wang, Y.-Y.; Han, Y.-F. TemplateDirected Photochemical $[2+2]$ Cycloaddition in Crystalline Materials: A Useful Tool to Access Cyclobutane Derivatives. Cryst. Growth Des. 2018, 18, 553-565. (b) Bibal, B.; Mongin, C.; Bassani, D. M. Template Effects and Supramolecular Control of Photoreactions in Solution. Chem. Soc. Rev. 2014, 43, 4179-4198.

(8) For selected examples, see: (a) Ito, Y.; Borecka, B.; Trotter, J.; Scheffer, J. R. Control of Solid-State Photodimerization of transCinnamic Acid by Double Salt Formation with Diamines. Tetrahedron Lett. 1995, 36, 6083-6086. (b) Ito, Y.; Hosomi, H.; Ohba, S. Compelled Orientational Control of the Solid-State Photodimerization of trans-Cinnamamides: Dicarboxylic Acid as a Non-covalent Linker. Tetrahedron 2000, 56, 6833-6844. (c) MacGillivray, L. R.; Reid, J. L.; Ripmeester, J. A. Supramolecular Control of Reactivity in the Solid State Using Linear Molecular Templates. J. Am. Chem. Soc. 2000, 122, 7817-7818. (d) Bassani, D. M.; Darcos, V.; Mahony, S.; Desvergne, J.-P. Supramolecular Catalysis of Olefin $[2+2]$ Photodimerization. J. Am. Chem. Soc. 2000, 122, 8795-8796. (e) Caronna, T.; Liantonio, R.; Logothetis, T. A.; Metrangolo, P.; Pilati, T.; Resnati, G. Halogen Bonding and e.... Stacking Control Reactivity in the Solid State. J. Am. Chem. Soc. 2004, 126, 4500-4501. (f) Friščić, T.; MacGillivray, L. R. Reversing the Code of a TemplateDirected Solid-State Synthesis: A Bipyridine Template that Directs a Single-Crystal-to-Single-Crystal $[2+2]$ Photodimerisation of a Dicarboxylic Acid. Chem. Commun. 2005, 5748-5750. (g) Mei, X.; Liu, S.; Wolf, C. Template-Controlled Face-to-Face Stacking of
Olefinic and Aromatic Carboxylic Acids in the Solid State. Org. Lett. 2007, 9, 2729-2732. (h) Bhogala, B. R.; Captain, B.; Parthasarathy, A.; Ramamurthy, V. Thiourea as a Template for Photodimerization of Azastilbenes. J. Am. Chem. Soc. 2010, 132, 13434-13442. (i) Laird, R. C.; Sinnwell, M. A.; Nguyen, N. P.; Swenson, D. C.; Mariappan, S. V. S.; MacGillivray, L. R. Intramolecular $[2+2]$ Photodimerization Achieved in the Solid State via Coordination-Driven Self-Assembly. Org. Lett. 2015, 17, 3233-3235. (j) Sinnwell, M. A.; MacGillivray, L. R. Halogen-Bond-Templated [2+2] Photodimerization in the Solid State: Directed Synthesis and Rare Self-Inclusion of a Halogenated Product. Angew. Chem. 2016, 128, 3538-3541. (k) Quentin, J.; MacGillivray, L. R. Halogen versus Hydrogen Bonding in Binary Cocrystals: Novel Conformation a Coformer with $[2+2]$ Photoreactivity of Criss-Crossed C $=\mathrm{C}$ Bonds. ChemPhysChem 2020, 21, 154-163. (1) MacGillivray, L. R.; Papaefstathiou, G. S.; Friscic, T.; Hamilton, T. D.; Bucar, D.-K.; Chu, Q.; Varshney, D. B.; Georgiev, I. G. Supramolecular Control of Reactivity in the Solid State: From Templates to Ladderanes to Metal-Organic Frameworks. Acc. Chem. Res. 2008, 41, 280-291.

(9) For selected examples of the use of hydrogen bonding templates for photochemical $[2+2]$ cycloadditions in solution, see: (a) Müller, C.; Bauer, A.; Bach, T. Light-Driven Enantioselective Organocatalysis. Angew. Chem., Int. Ed. 2009, 48, 6640-6642. (b) Müller, C.; Bauer, A.; Maturi, M. M.; Cuquerella, M. C.; Miranda, M. A.; Bach, T. Enantioselective Intramolecular [2+2]-Photocycloaddition Reactions of 4-Substituted Quinolones Catalyzed by a Chiral Sensitizer with a Hydrogen-Bonding Motif. J. Am. Chem. Soc. 2011, 133, 1668916697. (c) Alonso, R.; Bach, T. A Chiral Thioxanthone as an Organocatalyst for Enantioselective $[2+2]$ Photocycloaddition Reactions Induced by Visible Light. Angew. Chem., Int. Ed. 2014, 53, 4368-4371. (d) Telmesani, R.; Park, S. H.; Lynch-Colameta, T.; Beeler, A. B. $[2+2]$ Photocycloaddition of Cinnamates in Flow and Development of a Thiourea Catalyst. Angew. Chem., Int. Ed. 2015, 54, 11521-11525. For a review, see: (e) Brimioulle, R.; Lenhart, D.; Maturi, M. M.; Bach, T. Enantioselective Catalysis of Photochemical Reactions. Angew. Chem., Int. Ed. 2015, 54, 3872-3890.

(10) For photochemical homodimerization reactions of cinnamic acids inside cucurbit[8]uril and $\gamma$-cyclodextrin hosts, see: (a) Pattabiraman, M.; Natarajan, A.; Kaanumalle, L. S.; Ramamurthy, V. Templating Photodimerization of trans-Cinnamic Acids with Cucurbit[8] uril and -Cyclodextrin. Org. Lett. 2005, 7, 529-532. (b) Nguyen, N.; Clements, A. R.; Pattabiraman, M. Using Noncovalent Interactions to Direct Regioselective $2+2$ Photocycloaddition within a Macrocyclic Cavitand. New J. Chem. 2016, 40, 2433-2443.

(11) Haag, D.; Scharf, H.-D. Investigations of the Asymmetric Intramolecular $[2+2]$ Photocycloaddition and Its Application as a Simple Access to Novel $C_{2^{-}}$Symmetric Chelating Biphosphanes Bearing a Cyclobutane Backbone. J. Org. Chem. 1996, 61, 6127-6135.

(12) König, B.; Leue, S.; Horn, C.; Caudan, A.; Desvergne, J.-P.; Bouas-Laurent, H. Synthesis of Medium-Size Macrocycles by Cinnamate $[2+2]$ Photoaddition. Liebigs Ann. 1996, 1996, 12311233.

(13) Zitt, H.; Dix, I.; Hopf, H.; Jones, P. G. 4,15-Diamino[2.2]paracyclophane, a Reusable Template for Topochemical Reaction Control in Solution. Eur. J. Org. Chem. 2002, 2002, 2298-2307.

(14) Yuasa, H.; Nakatani, M.; Hashimoto, H. Exploitation of Sugar Ring Flipping for a Hinge-type Tether Assisting a $[2+2]$ Cycloaddition. Org. Biomol. Chem. 2006, 4, 3694-3702.

(15) Ghosn, M. W.; Wolf, C. Stereocontrolled Photodimerization with Congested 1,8-Bis (4'-anilino)naphthalene Templates. J. Org. Chem. 2010, 75, 6653-6659.

(16) (a) Greiving, H.; Hopf, H.; Jones, P. G.; Bubenitschek, P.; Desvergne, J.-P.; Bouas-Laurent, H. Synthesis, Photophysical and Photochemical Properties of Four [2.2] 'Cinnamophane' Isomers; Highly Efficient Stereospecific [2 + 2] Photocycloaddition. J. Chem. Soc., Chem. Commun. 1994, 1075-1076. (b) Greiving, H.; Hopf, H.; Jones, P. G.; Bubenitschek, P.; Desvergne, J.-P.; Bouas-Laurent, H. Synthesis, Photophysical and Photochemical Properties of Cinnamo- 
phanes. Liebigs Ann. 1995, 1995, 1949-1956. (c) Hopf, H.; Greiving, H.; Jones, P. G.; Bubenitschek, P. Topochemical Reaction Control in Solution. Angew. Chem., Int. Ed. Engl. 1995, 34, 685-687.

(17) Nguyen, T. B.; Al-Mourabit, A. Remarkably High Homoselectivity in $[2+2]$ Photodimerization of trans-Cinnamic Acids in Multicomponent Systems. Photochem. Photobiol. Sci. 2016, 15, 11151119.

(18) (a) Lei, T.; Zhou, C.; Huang, M.-Y.; Zhao, L.-M.; Yang, B.; Ye, C.; Xiao, H.; Meng, Q.-Y.; Ramamurthy, V.; Tung, C.-H.; Wu, L.-Z. General and Efficient Intermolecular [2 + 2] Photodimerization of Chalcones and Cinnamic Acid Derivatives in Solution through Visible Light Catalysis. Angew. Chem., Int. Ed. 2017, 56, 15407-15410. (b) Wu, Q.-A.; Chen, F.; Ren, C.-R.; Liu, X.-F.; Chen, H.; Xu, L.-X.; Yu, X.-C.; Luo, S.-P. Donor-Acceptor Fluorophores as Efficient Energy Transfer Photocatalysts for [2+2] Photodimerization. Org. Biomol. Chem. 2020, 18, 3707-3716.

(19) For a photocatalytic [2 +2] cycloaddition between cinnamate esters and styrenes, see: Daub, M. E.; Jung, H.; Lee, B. J.; Won, J.; Baik, M.-H.; Yoon, T. P. Enantioselective [2 +2$]$ Cycloadditions of Cinnamate Esters: Generalizing Lewis Acid Catalysis of Triplet Energy Transfer. J. Am. Chem. Soc. 2019, 141, 9543-9547.

(20) (a) Hung, J. D.; Lahav, M.; Luwisch, M.; Schmidt, G. M. J. Topochemistry. Part XXXV. The Formation of Mixed Dimers from Solid Solutions of trans-Cinnamic Acids and trans-Cinnamides. Isr. J. Chem. 1972, 10, 585-599. (b) Cohen, M. D.; Cohen, R.; Lahav, M.; Nie, P. L. Topochemistry. Part XXXVI. Relative Yields of Photodimers from Mixed Crystals of trans-Cinnamic Acids and transCinnamides. J. Chem. Soc., Perkin Trans. 2 1973, 1095-1100. (c) Desiraju, G. R.; Sharma, C. V. K. M. C-H...O Hydrogen Bonding and Topochemistry in Crystalline 3,5-Dinitrocinnamic Acid and Its 1:1 Donor-Acceptor Complex with 2,5-Dimethoxycinnamic Acid. J. Chem. Soc., Chem. Commun. 1991, 1239-1241. (d) Maekawa, Y.; Kato, S.; Hasegawa, M. Quantitative Formation of a Highly Strained Tricyclic [2.2] Paracyclophane Derivative from a Mixed Crystal of Ethyl and Propyl [-Cyano-4-[2-(4-pyridyl)ethenyl]cinnamates. J. Am. Chem. Soc. 1991, 113, 3867-3872. (e) Kinbara, K.; Adegawa, Y.; Saigo, K.; Hasegawa, M. Formation of a Topochemically Photoreactive Mixed Crystal by Grinding and Its Mechanistic Interpretation. Bull. Chem. Soc. Jpn. 1993, 66, 1204-1210. (f) Coates, G. W.; Dunn, A. R.; Henling, L. M.; Ziller, J. W.; Lobkovsky, E. B.; Grubbs, R. H. Phenyl-Perfluorophenyl Stacking Interactions: Topochemical [2 $+2]$ Photodimerization and Photopolymerization of Olefinic Compounds. J. Am. Chem. Soc. 1998, 120, 3641-3649. (g) Grove, R. C.; Malehorn, S. H.; Breen, M. E.; Wheeler, K. A. A Photoreactive Crystalline Quasiracemate. Chem. Commun. 2010, 46, 7322-7324. (h) Wheeler, K. A.; Wiseman, J. D.; Grove, R. C. Enantiocontrolled Solid-State Photodimerizations via a Chiral Sulfonamidecinnamic Acid. CrystEngComm 2011, 13, 3134-3137. (i) Khoj, M. A.; Hughes, C. E.; Harris, K. D. M.; Kariuki, B. M. Structural Diversity of Solid Solutions Formed between 3-Chloro-trans- cinnamic Acid and 3Bromo-trans-cinnamic Acid. Cryst. Growth Des. 2017, 17, 1276-1284. (21) Sinnwell, M. A.; Groeneman, R. H.; Ingenthron, B. J.; Li, C.; MacGillivray, L. R. Supramolecular Construction of a Cyclobutane Ring System with Four Different Substituents in the Solid State. Commun. Chem. 2021, 4, 60.

(22) (a) Mammadova, F.; Hamarat, B.; Ahmadli, D.; Şahin, O.; Bozkaya, U.; Türkmen, Y. E. Polarization-Enhanced Hydrogen Bonding in 1,8-Dihydroxynaphthalene: Conformational Analysis, Binding Studies and Hydrogen Bonding Catalysis. ChemistrySelect 2020, 5, 13387-13396. (b) Türkmen, Y. E. Investigation of the Hydrogen Bond Donating Ability of 1,8-Naphthalenediol by NMR Spectroscopy and Its Use as a Hydrogen Bonding Catalyst. Turk. J. Chem. 2018, 42, 1398-1407.

(23) The distance between the two oxygens in the crystal structure of $1,8-\mathrm{DHN}(6)$ is $2.58 \AA$ (ref 22a).

(24) Aung, T.; Liberko, C. A. Bringing Photochemistry to the Masses: A Simple, Effective, and Inexpensive Photoreactor, Right Out of the Box. J. Chem. Educ. 2014, 91, 939-942.
(25) See the Supporting Information (SI) for the images of photoreaction setups and for the UV-vis spectra of several substrates and cycloadducts.

(26) See the SI for details.

(27) Harada, J.; Ogawa, K. Pedal Motion in Crystals. Chem. Soc. Rev. 2009, 38, 2244-2252.

(28) (a) Ohba, S.; Hosomi, H.; Ito, Y. In Situ X-ray Observation of Pedal-like Conformational Change and Dimerization of transCinnamamide in Cocrystals with Phthalic Acid. J. Am. Chem. Soc. 2001, 123, 6349-6352. (b) Chu, Q.; Swenson, D. C.; MacGillivray, L. R. A Single-Crystal-to-Single-Crystal Transformation Mediated by Argentophilic Forces Converts a Finite Metal Complex into an Infinite Coordination Network. Angew. Chem., Int. Ed. 2005, 44, 3569-3572. (c) Natarajan, A.; Mague, J. T.; Venkatesan, K.; Ramamurthy, V. Large Molecular Motions are Tolerated in Crystals of Diamine Double Salt of trans-Chlorocinnamic Acids with trans-1,2Diaminocyclohexane. Org. Lett. 2005, 7, 1895-1898. (d) Peedikakkal, A. M. P.; Vittal, J. J. Solid-State Photochemical [2+2] Cycloaddition in a Hydrogen-Bonded Metal Complex Containing Several Parallel and Crisscross C $=$ C Bonds. Chem. - Eur. J. 2008, 14, 5329-5334.

(29) Harada, J.; Ogawa, K. Invisible but Common Motion in Organic Crystals: A Pedal Motion in Stilbenes and Azobenzenes. J. Am. Chem. Soc. 2001, 123, 10884-10888. 